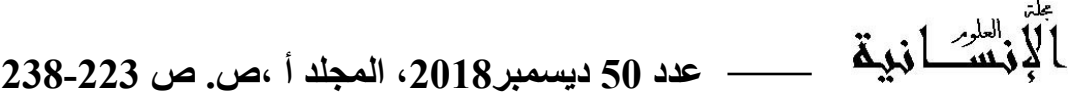

\section{الطعن بالنقض كآلية رقابة على الحكم الجنائي الصادر بالإدانة}

$$
\begin{aligned}
& \text { آمال مقري } \\
& \text { كلية الحقوق } \\
& \text { جامعة الإخوة منتوري } \\
& \text { قسنطينة1(الجز ائر) }
\end{aligned}
$$

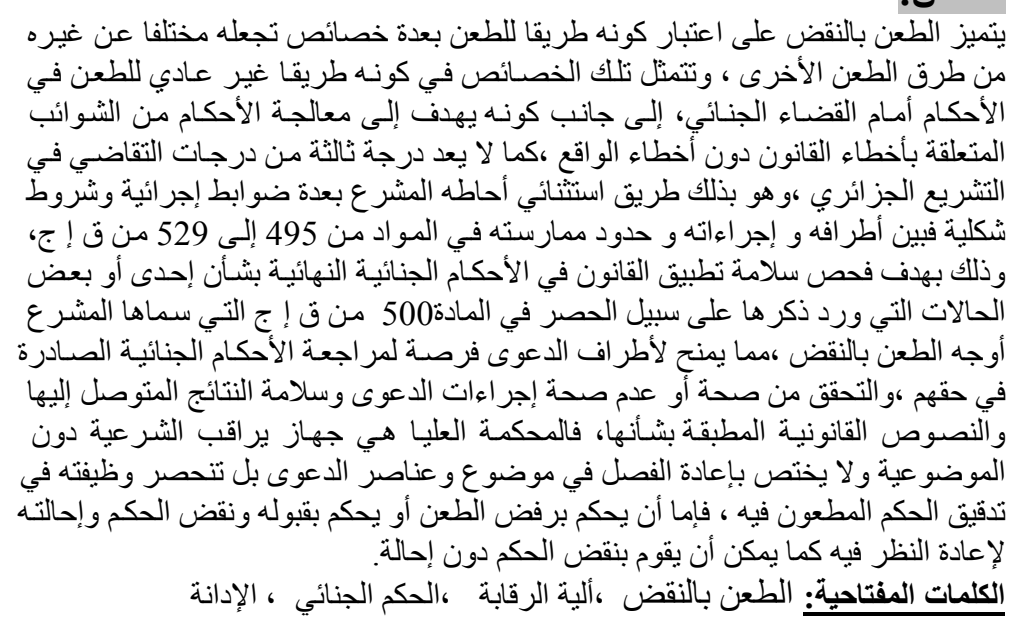

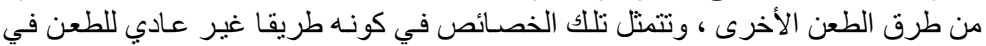

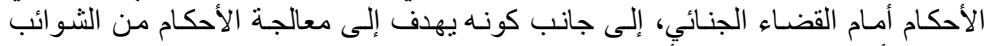

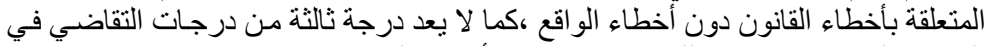

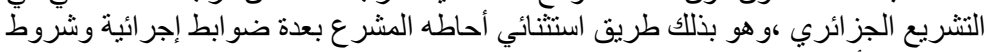

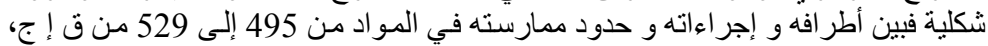

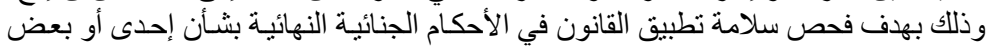
الحالات التي ورد ذكر ها على سبيل الحصر في المادة

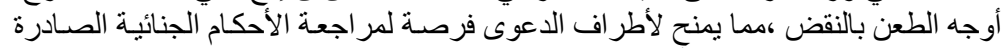

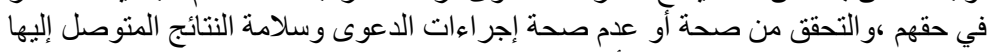

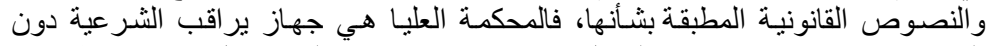

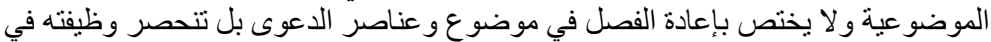

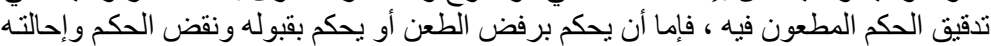

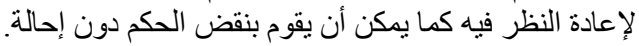

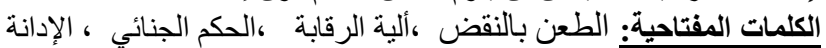

\section{Résumé:}

le pourvoi en cassation se caractérise comme un moyen de contester les jugements par un certain nombre de caractéristiques qui le rendent différent des autres moyens de voies de recours, à savoir les caractéristiques d'une manière extraordinaire pour contester les décisions de la justice pénale, tout en étant conçu pour répondre aux dispositions d'un but lié à des erreurs de droit, sans erreurs réelles, Il n'est également pas un troisième degré de juridiction dans la législation algérienne, et est donc exceptionnel il était entouré par le législateur de plusieurs contrôles procéduraux et formels entre les branches et les procédures et les limites de l'exercice dans les articles de 495 à 529 de C.P.P.A, dans le but de vérifier l'intégrité de l'application des lois dans les décisions définitives pénales sur un ou plusieurs des cas mentionnés par limitation à l'article 500 du C.P.P.A désigné par le législateur établit le pourvoi en cassation, en donnant aux parties l'occasion de réviser les condamnations criminelles dans leur droit, et la vérification de la validité ou la nullité de la procédure et la sécurité des conclusions et des textes applicables à ce sujet juridique, car la Cour suprême est un dispositif qui surveille l'objectif légitime ne s'applique pas à revoir les éléments de l'affaire, mais dans la vérification du jugement attaquée et elle examine seulement en vue de faire respecter la loi et de maintenir l'unité d'interprétation judiciaire, que se soit en rejetant le pourvoi ou en l'acceptant par une cassation avec renvoi en renvoyant le jugement à réexaminer, comme elle peut être une cassation sans renvoi.

2018 جامعة الإخوة منتوري قسنطينة، الجز ائر (C) 
وتقع على عاتق القضاء مهمة تطبيق القانون تطبيقا صحيحا من خـلال الإجر اءات الجنائيـة التي تهدف

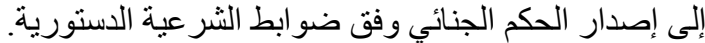

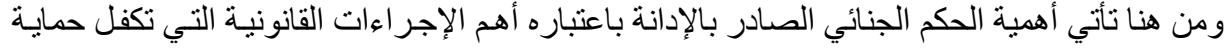

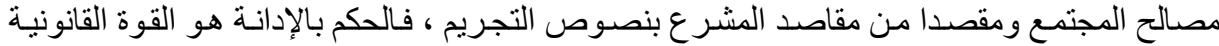

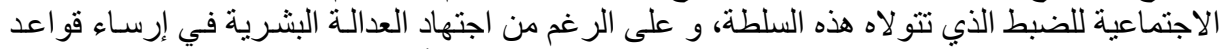

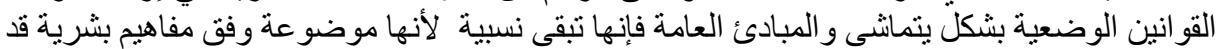

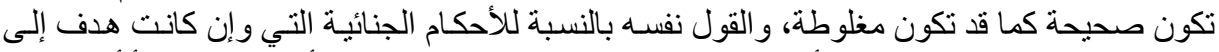

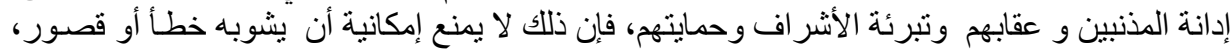

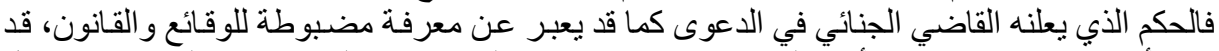

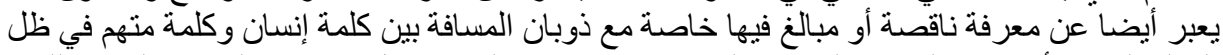

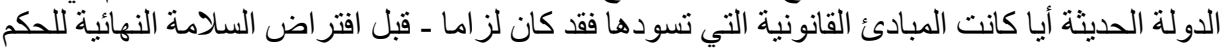

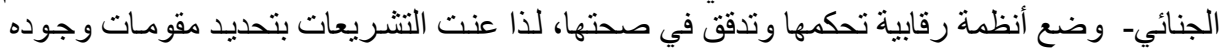

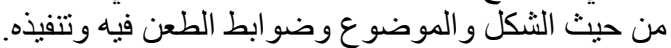

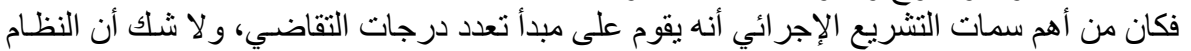

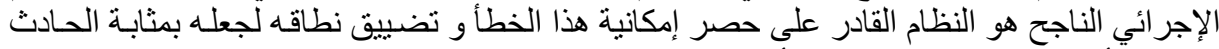

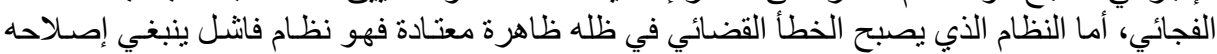
جملة وتفصبلا.

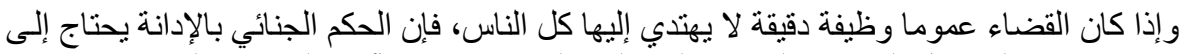

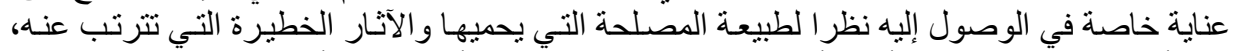

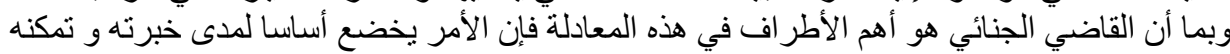

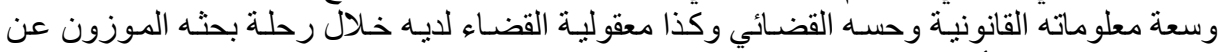

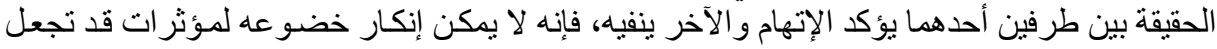

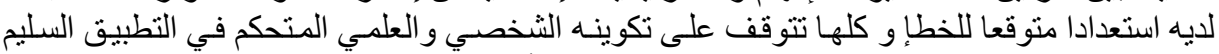

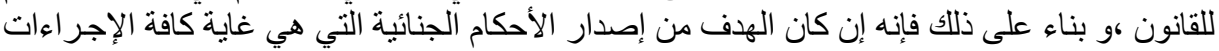

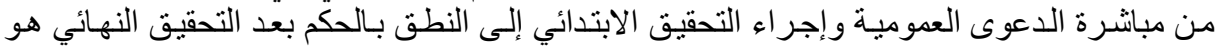

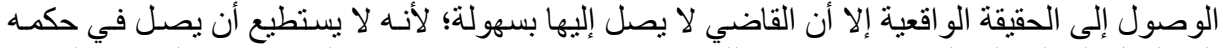

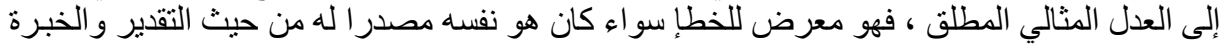

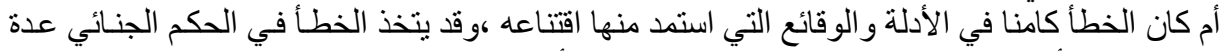

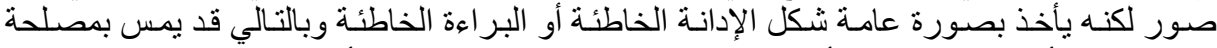

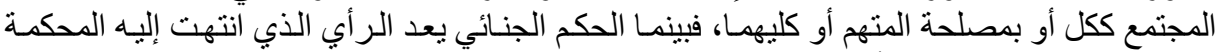

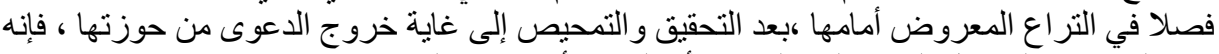

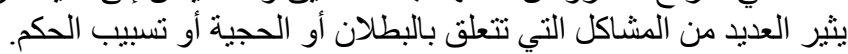

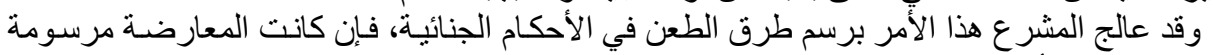

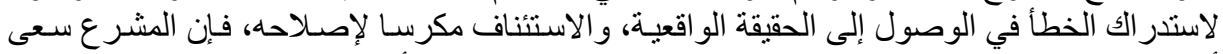

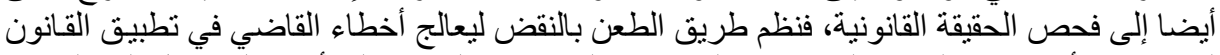

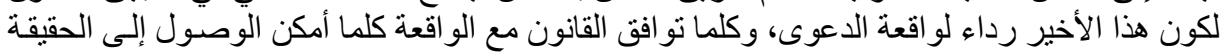

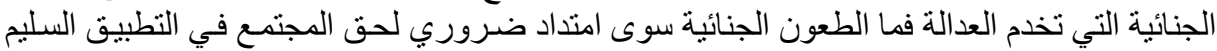
للقانون.

و من هنا تتكثف لنا الإشكالية التي سيتناولها الموضوع من خلال محاولتنا التوفيق بين أمرين متناقضين:

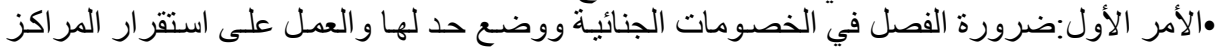
القانونية ، وذللك لا يتأتى إلا بإصدار الفحل فئي الحكم النهائي السليم قانونيا وو اقعيا.

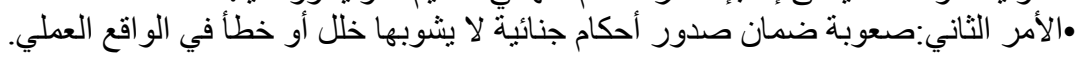




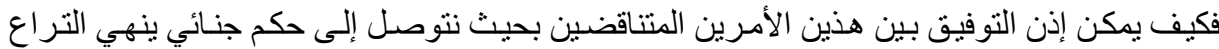

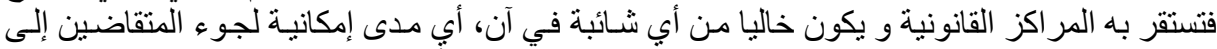

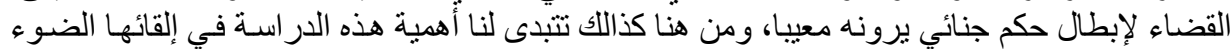
على الطعن بالنقض كآلية للارقابة على الحكم الجنائي الصادر بالئ بالإدانة.

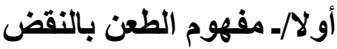

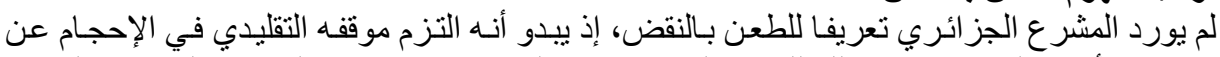

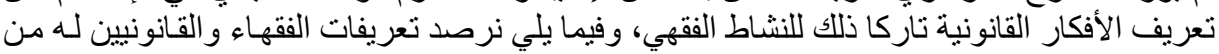

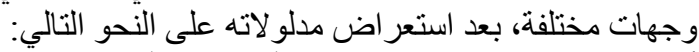

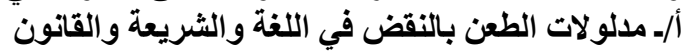

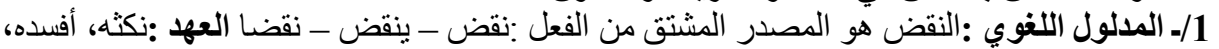

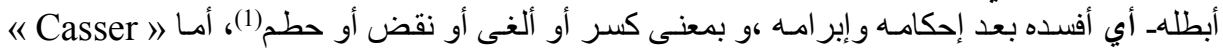

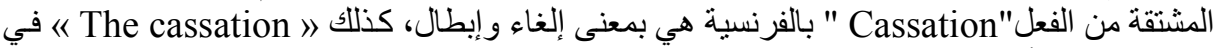
الإنجليزية فهو أيضا بمعنى الإلغاء و الإبطال

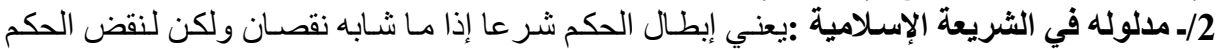

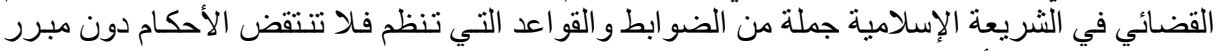

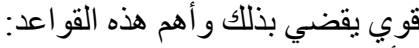

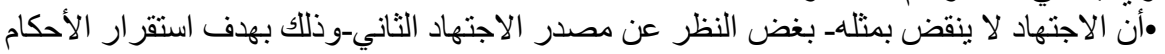

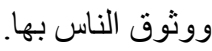
•السو ابق القضائية لا تلزم القاضي في الإسلام و لا تقيده، فإن اجتهد في مسألة وحكم فيها بحكم معين،

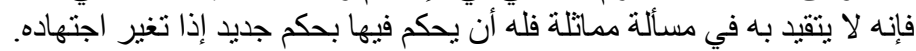

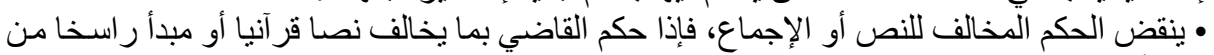

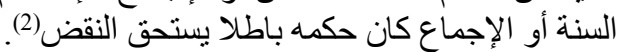

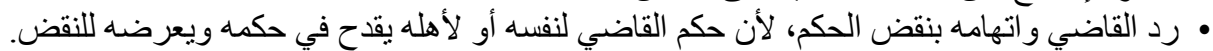

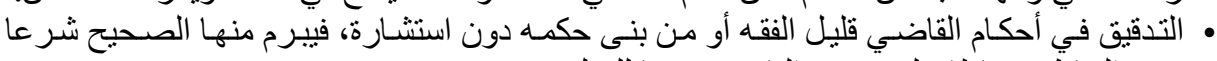

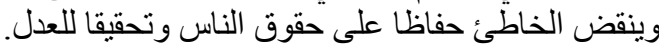

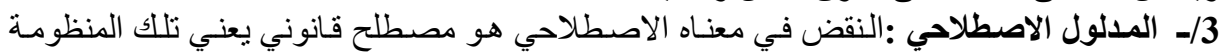

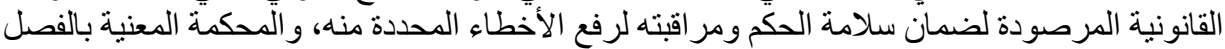

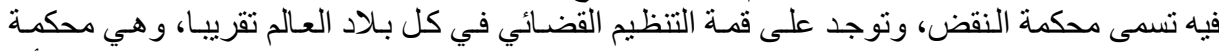

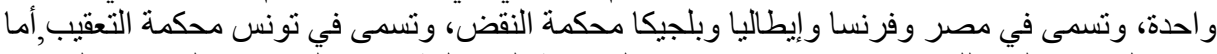

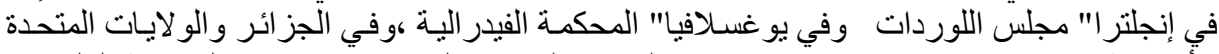

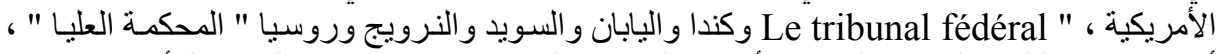

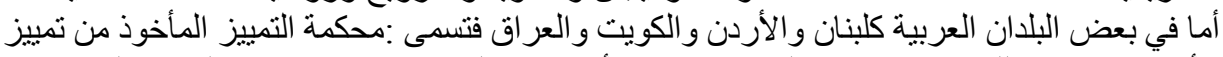

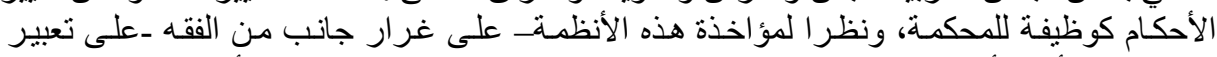

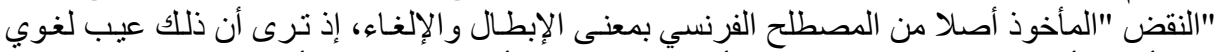

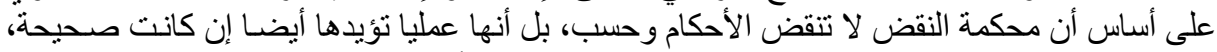

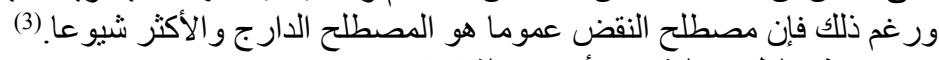
ب/ـ تعريف الطعن بالنقض وأس أساسه القانوني:

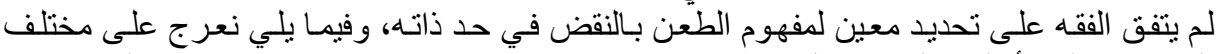

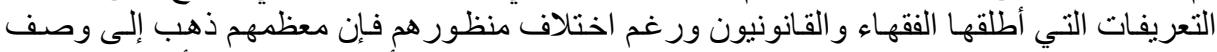

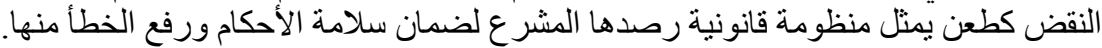
إذ يعرفه الدكتور محمد علي الكيلك على أنه: 


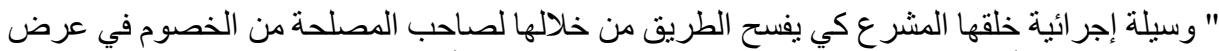

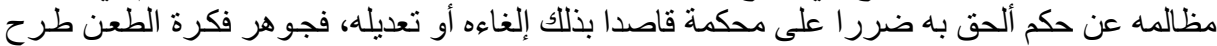

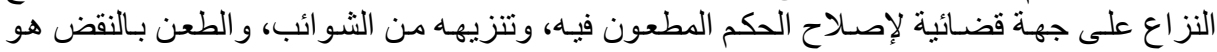

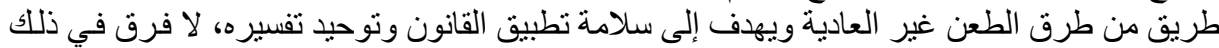

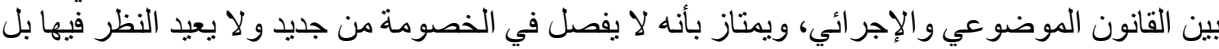

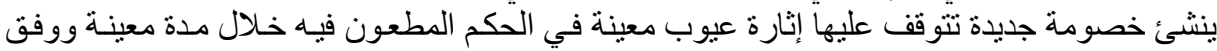

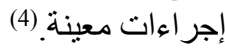
أما الدكتور المرصفاوي فقد رأى بأن: " طريق النقض يبتغى تحقيق نوع من الإثر اف لاف على تطبيق القانون وتفسبره، ليؤدي إلى توحيد المبادئ

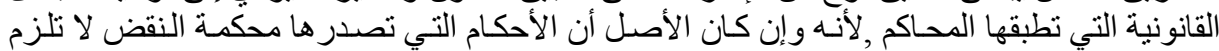

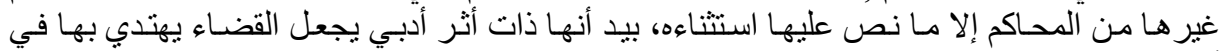

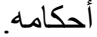

ويتميز الطعن بالنقض على الاستئناف بأنه يقتصر على فحص سلامة الحكم من الناحية العملية بإعمـال

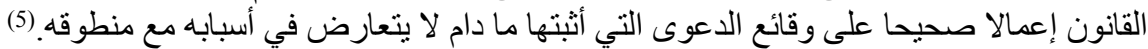

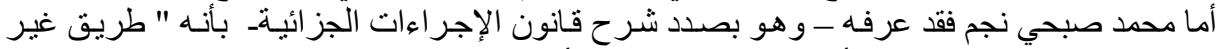

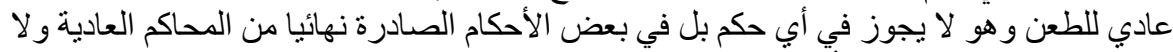

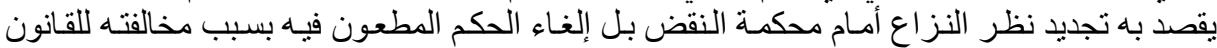

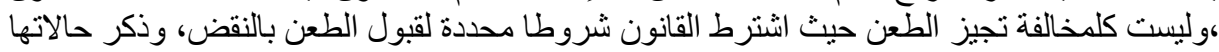

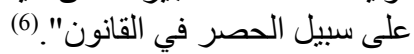

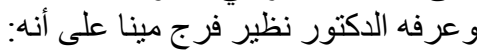

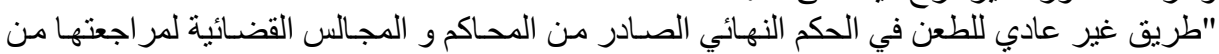

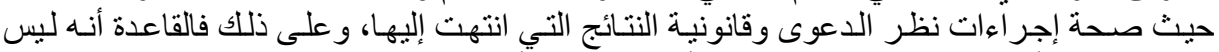

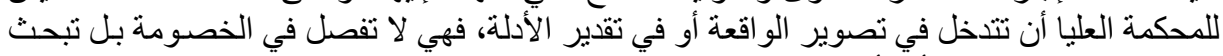

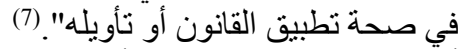

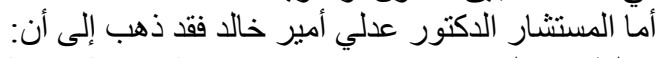

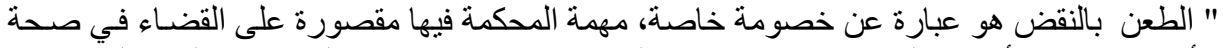

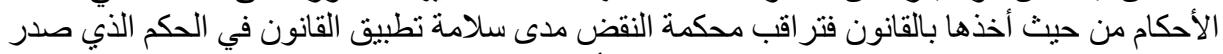

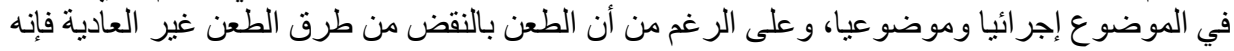

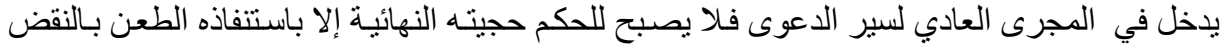

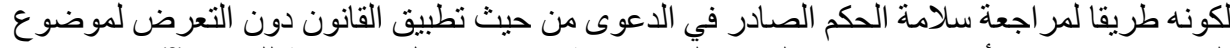

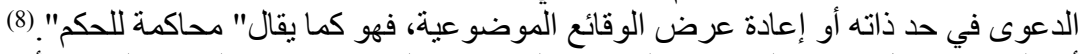

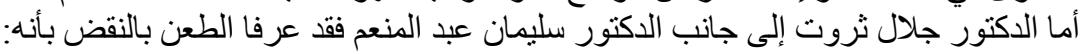

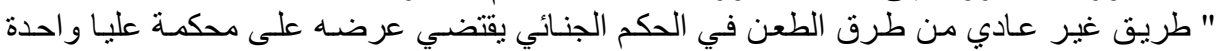

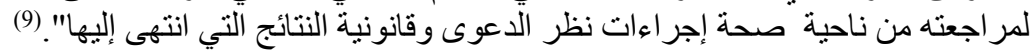

تعليق:

الملاحظ على هذه التعاريف أنها تتاولت جو انب الطعن بالنقض الموضو عية و الإجر ائية في آن معا، ذلك

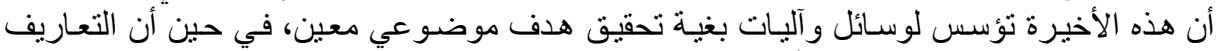

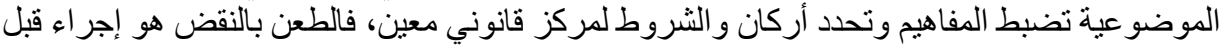

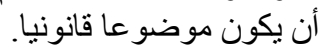

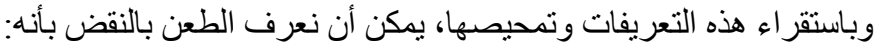

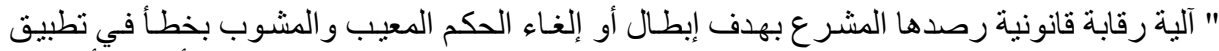

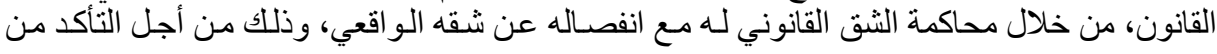


صحته ومطابقته لأحكام القانون، بهدف توحيد القضاء، وبالتالي تحقيق مبدأ مساو اة الأفر اد أمسام القانون

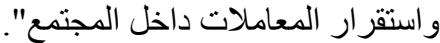

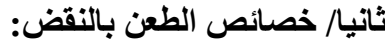

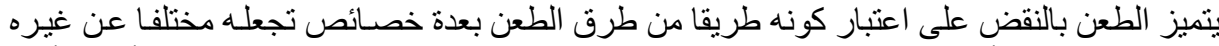

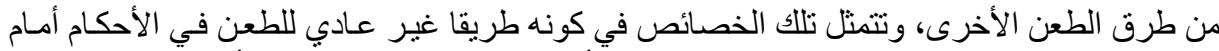

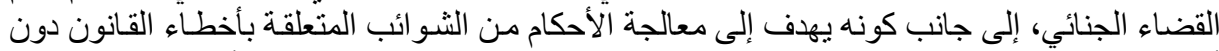

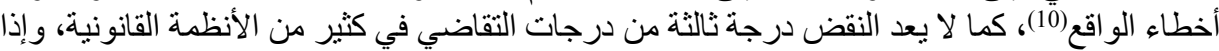

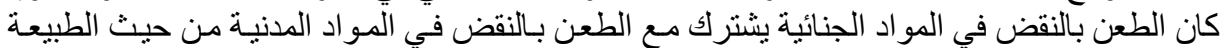

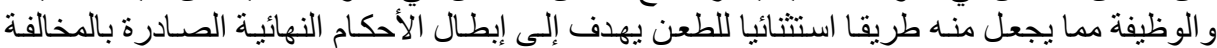

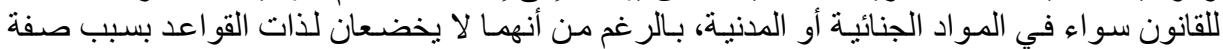

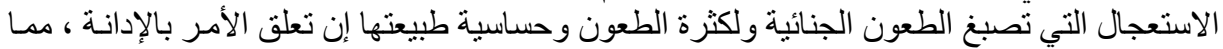

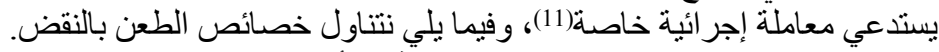

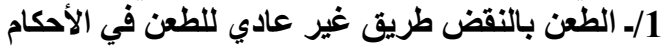

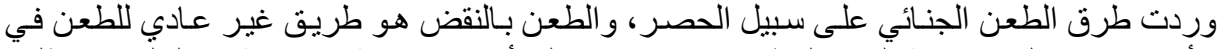

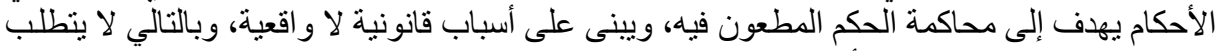

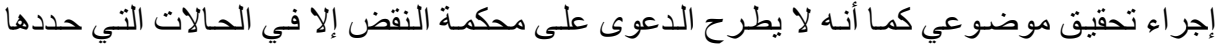

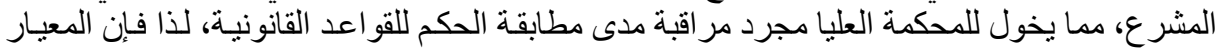

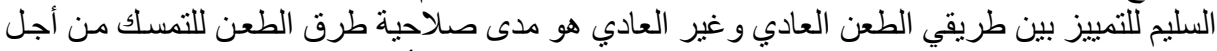

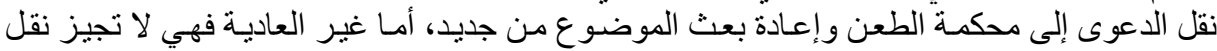

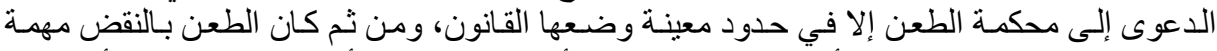

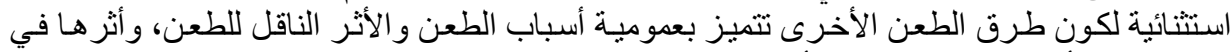

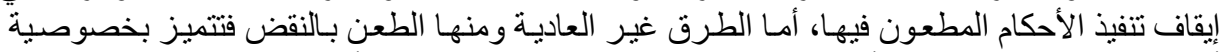

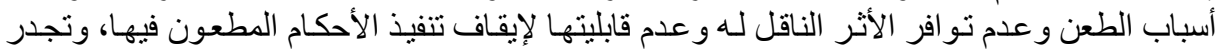

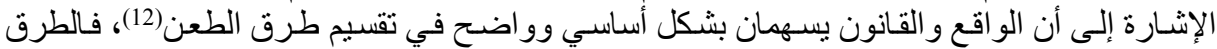

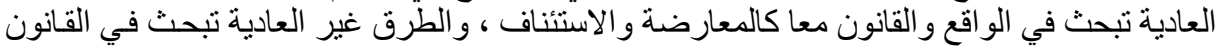

فقط كالطعن بالنقض، أوفي تأثثير الو اقعة التي جدت بعد الحكم على مضمونه كالتماس إعادة النظر.

2/2 الطعن بالنقض يقتصر على معالجة أخطاء القانون

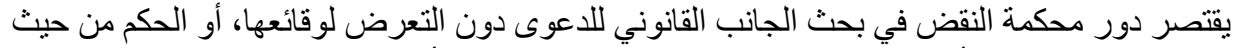

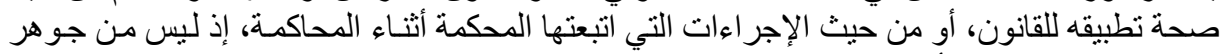

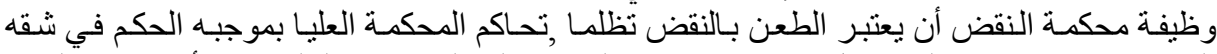

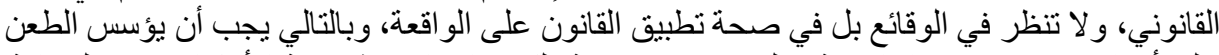

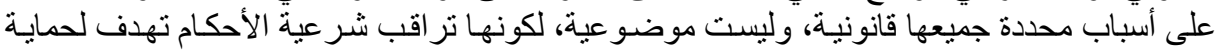

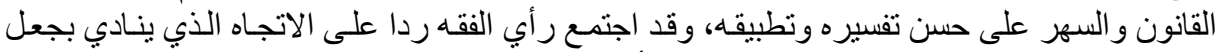

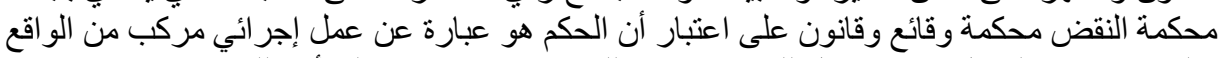

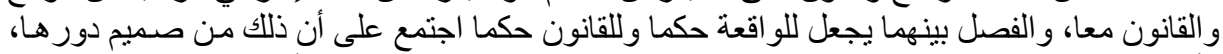

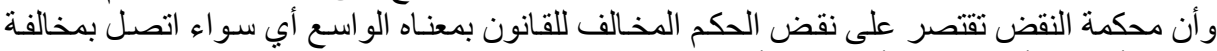

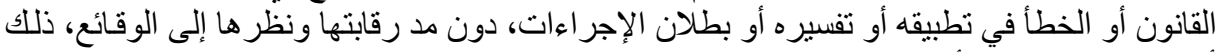

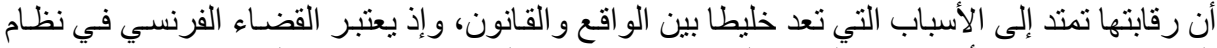

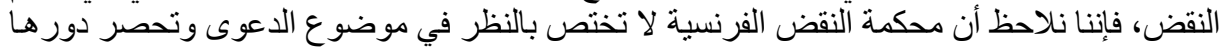
في مر اقبة السلامة القانونية للحكم، وذلك بصريح النصانصة(13)، ولعل الدور الهام الذي يضطلع بـه الطعن 
بالنقض في توحيد وتتسيق وتفسير القانون، ودور محكمة النقض في كفالة وحدة القضاء و استقر اره هو

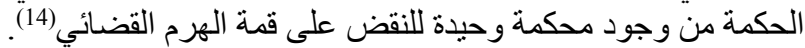

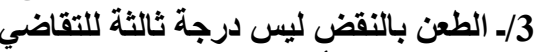

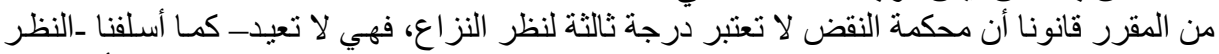

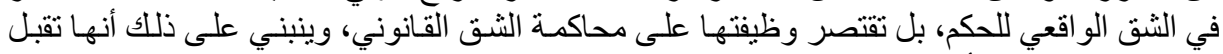

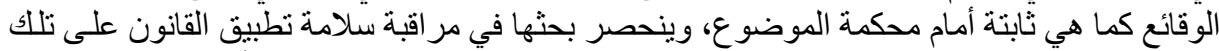

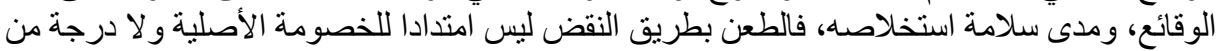

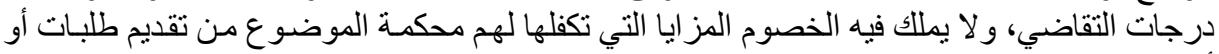

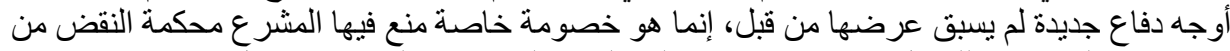

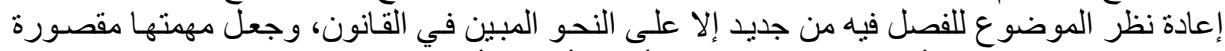

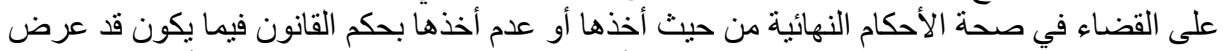

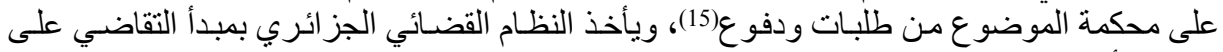

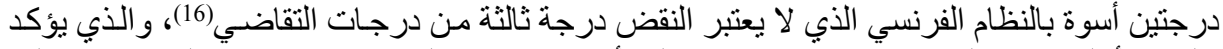

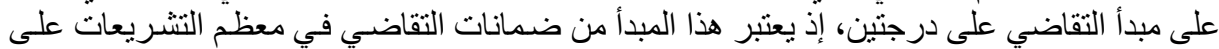

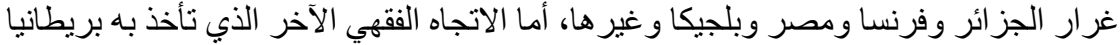

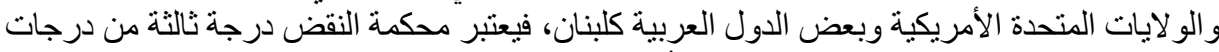

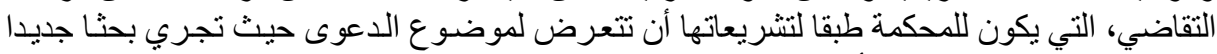

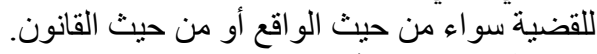

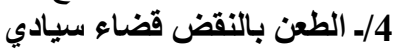

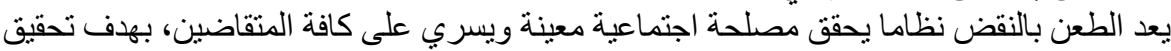

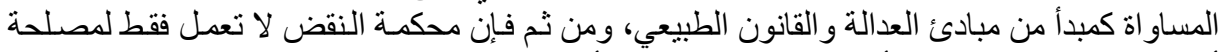

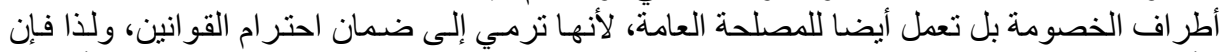

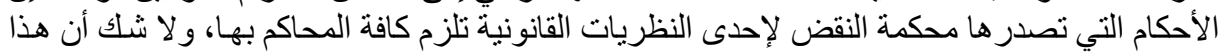

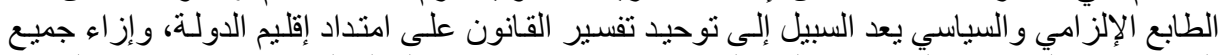

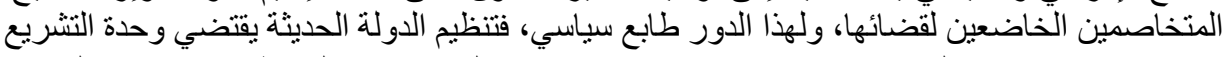

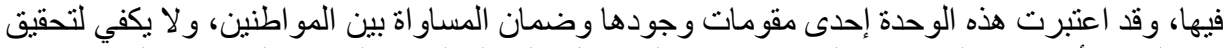

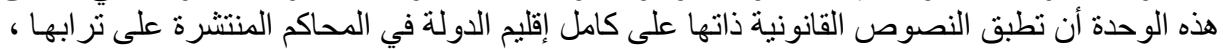

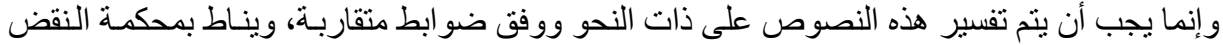
دور ضبط هذا التفسير وتحقيق وحدنه(17).

ثُالثا/. إجراءات مباشرة الطعن بالنقض وشروطه الثكلية:

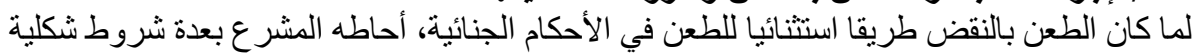

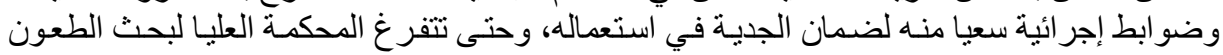

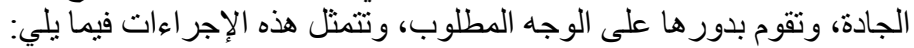

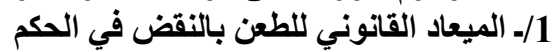

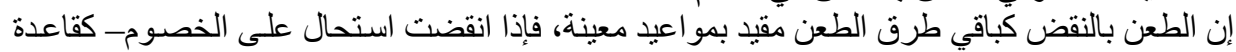

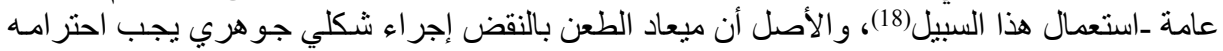

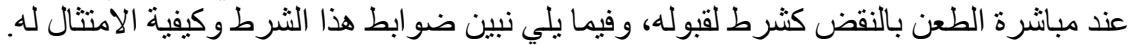

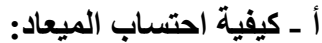

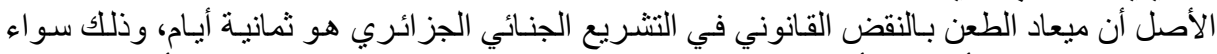

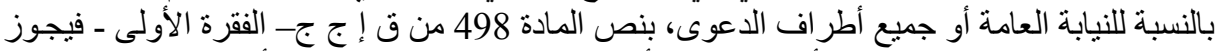
الطعن فور صدور الحكم بالإدانة أو في الثمانية أيام التالية ليوم صدوره بالئ بالنسبة لأطر اف الدعوى، الذين 
حضروا أو حضر من ينوب عنهم يوم النطق بـالحكم، و إذا كان اليوم الأخير لبس من أيسام العمل في

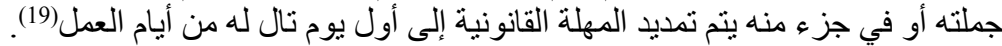

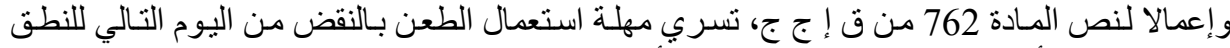

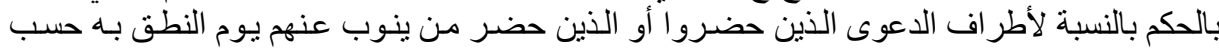

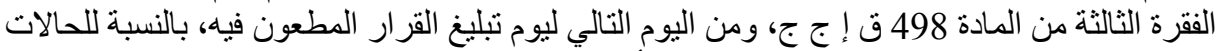

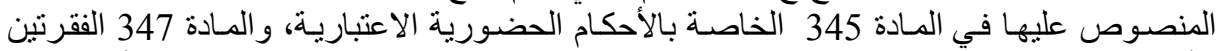

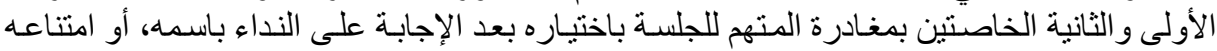

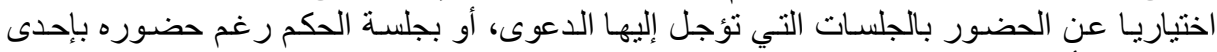

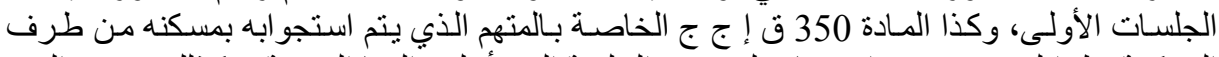

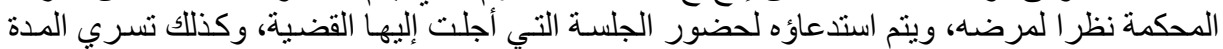

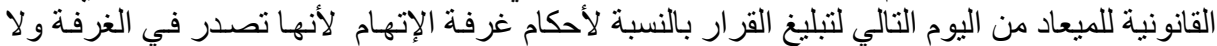

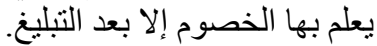

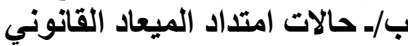

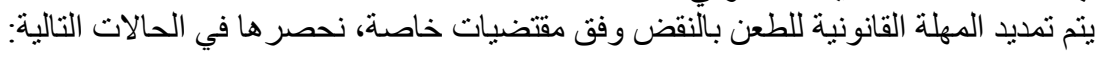

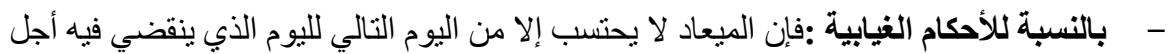

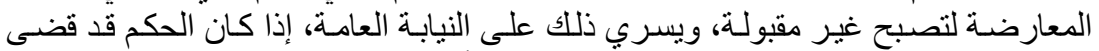

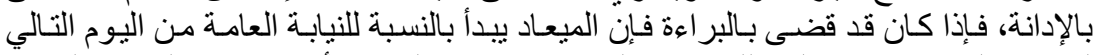

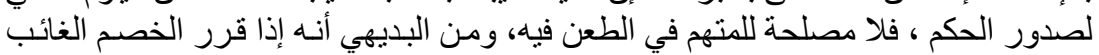

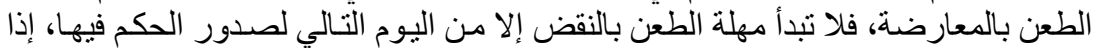

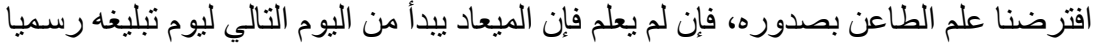

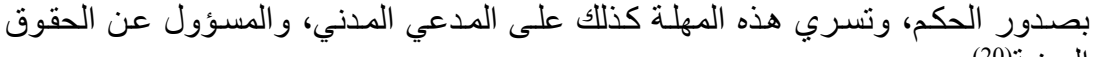

$$
\text { المدنية(20). }
$$

\section{- - مي حالة إقامة احد أطراف الدعوى خارج البلاد :}

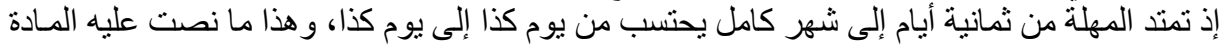

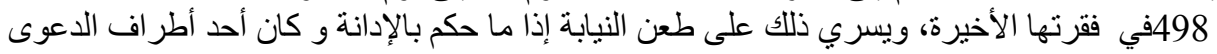

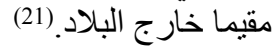

$$
\text { - }
$$

و العذر القهرب المانع هو الببب الذي يحول دون إلعان إكانية مباثرة الطعن بالنقض في الحكم بالإدانة خلال

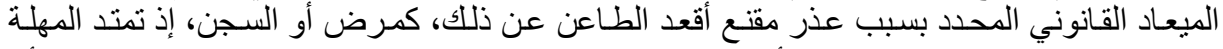

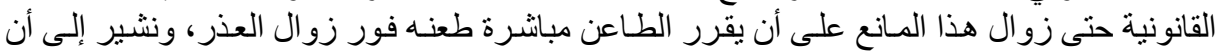

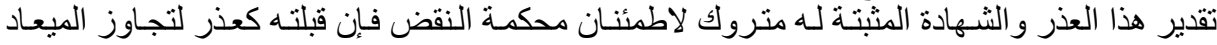

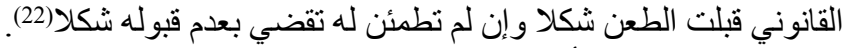

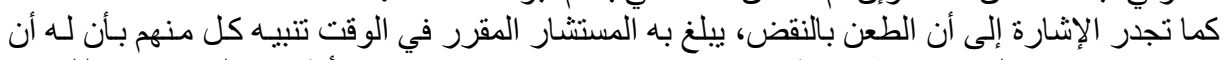

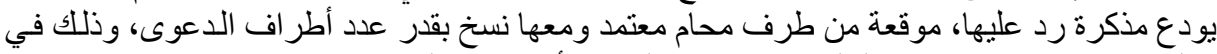

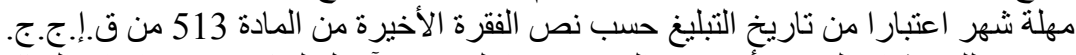

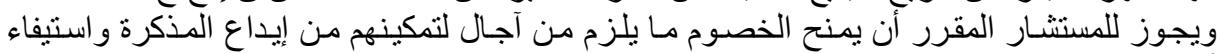

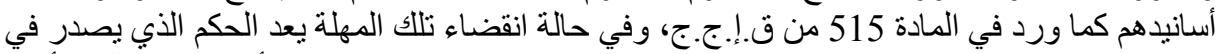

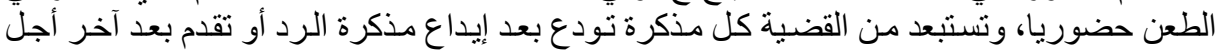




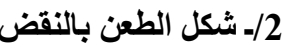

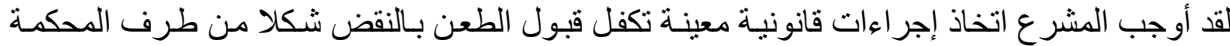

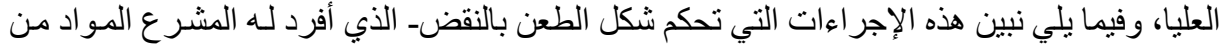
504 إلى512 من ق إ ج ج- وذن اللك على النحو التالي:

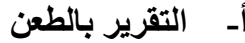

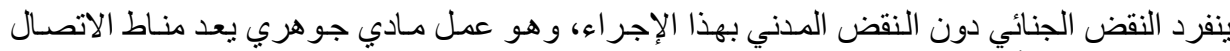

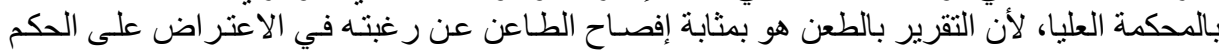

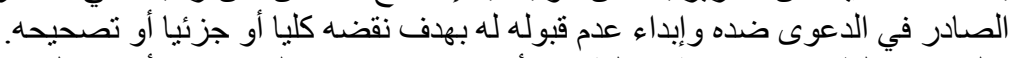

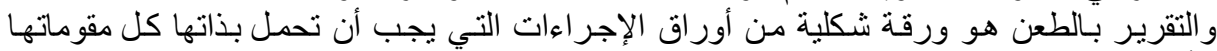

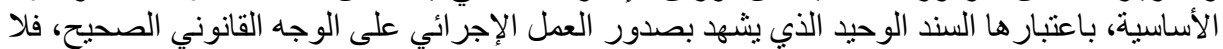

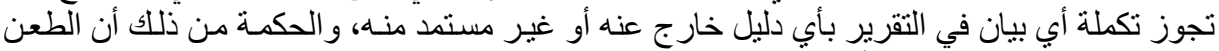

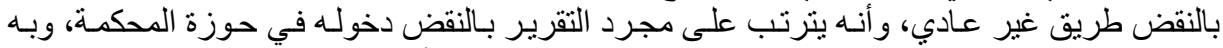
تتصل محكمة النقض بالطعن و الحكم المطعون فيه، لكل ذللك وجب أن تحمل ولن ورقة التقرير كل مقوماتـه

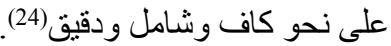

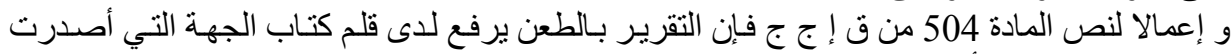

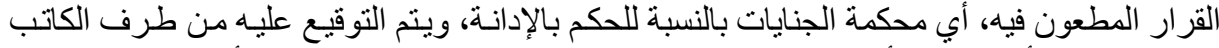

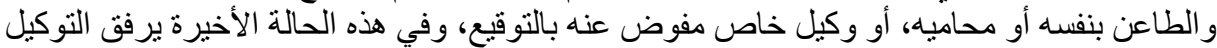

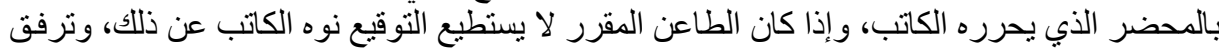
نسخة من المحضر ونسخة من التقرير بملف القالف القضية.

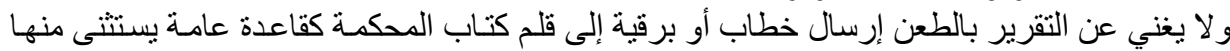

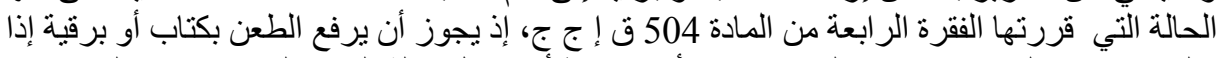

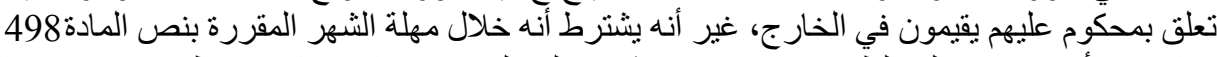

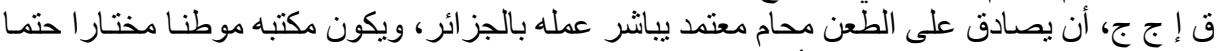

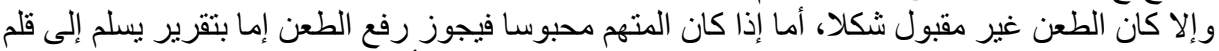

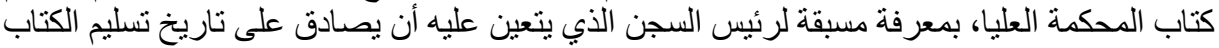

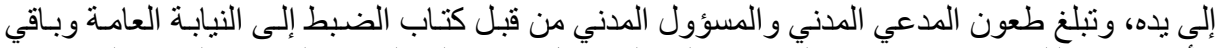

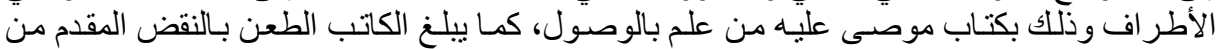

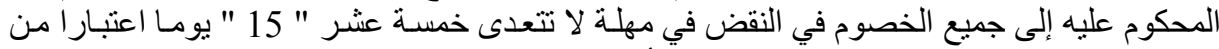

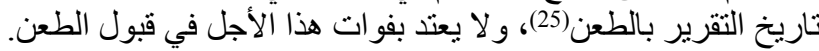

با- إيداع مذكرة بأسباب وأوجه الطعن

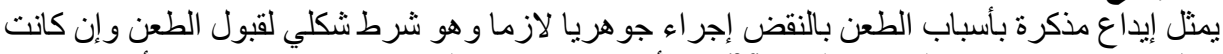

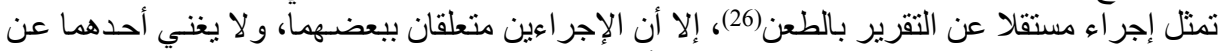

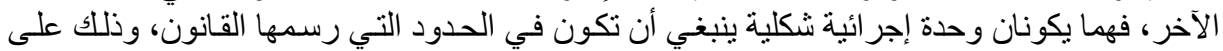

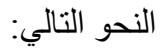

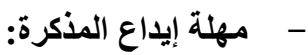

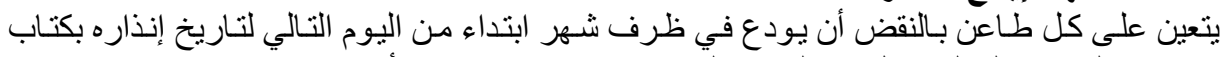

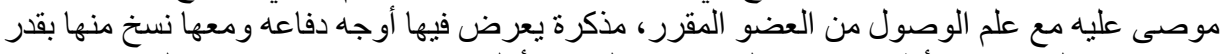

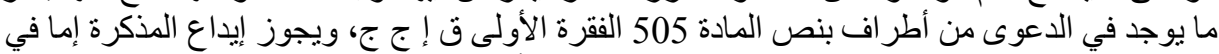

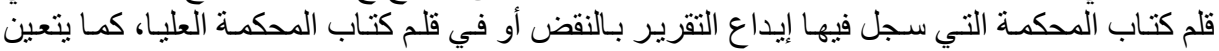

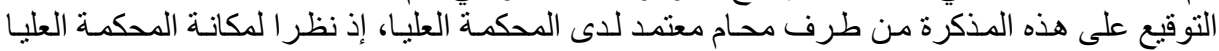
و عظم المسؤولية الملقاة على عاتق مستشاريها وقضائها 
في إرساء دعائم القانون وتوحيد تطبيقه في أرجاء البلاد، وحتى تتفر غ المحكمة لبحث ما جل من الأمور

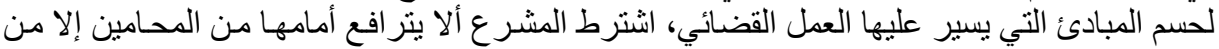

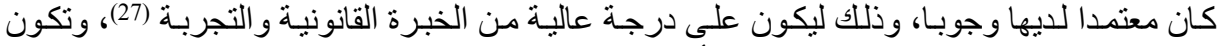

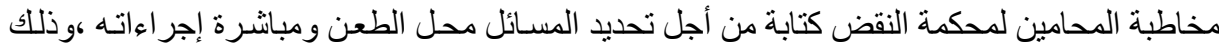

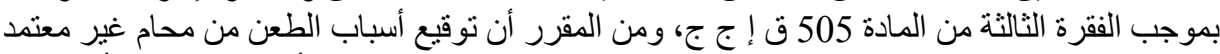

لاى المحكمة العليا يترتب عليه عدم قبول الطعن شكلا، ويستوي بعدم توقيع الأسباب من محام أصلا

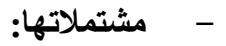

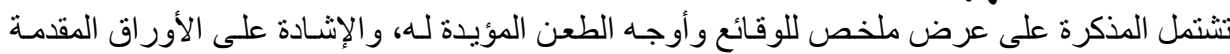

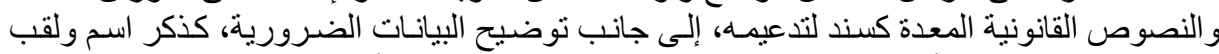

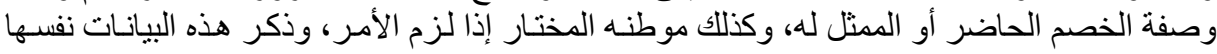

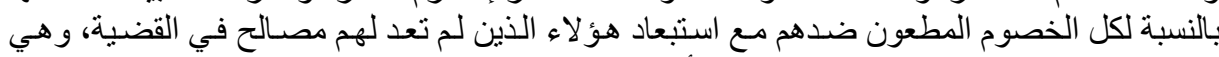
بيانات إلز امية في الدذكرات المودعة بات باسم الأطر اف.

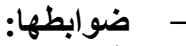

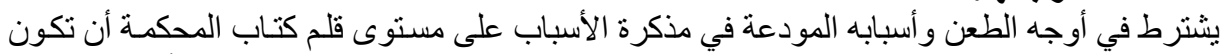

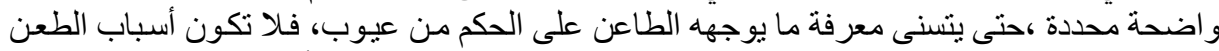

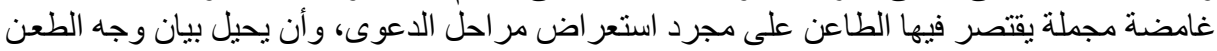

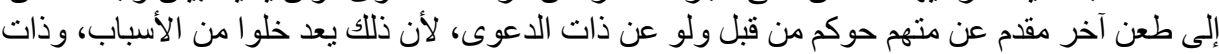

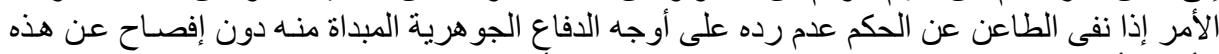

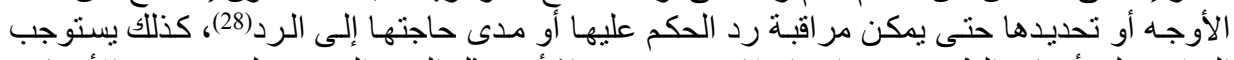

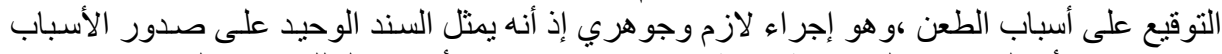

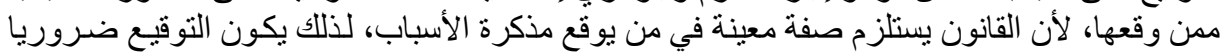

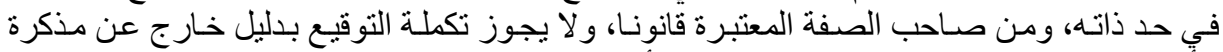

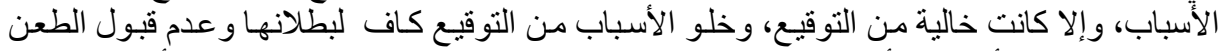

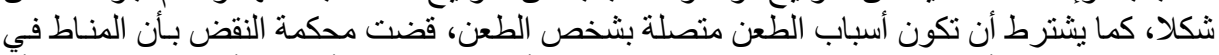

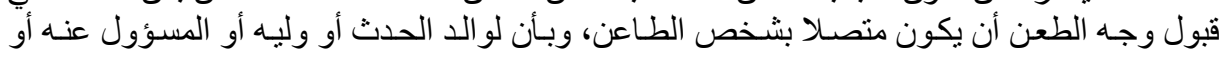
النائب عنه النه الطعن

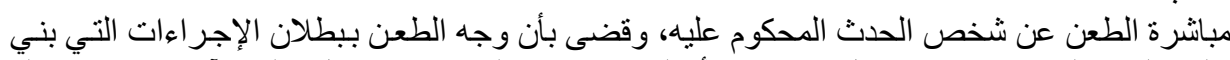

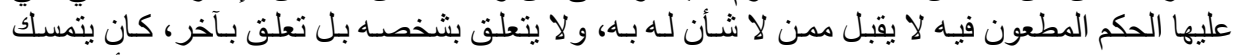

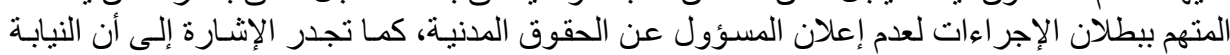

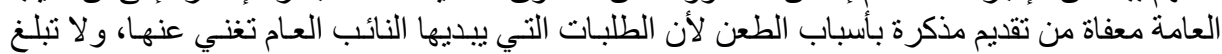

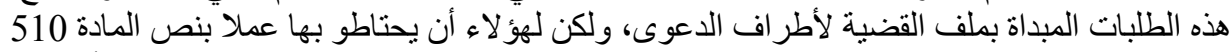

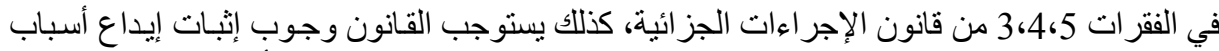

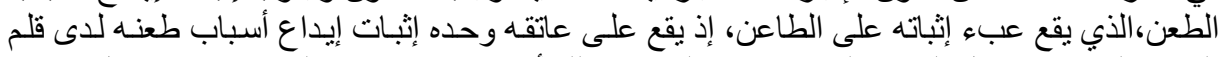

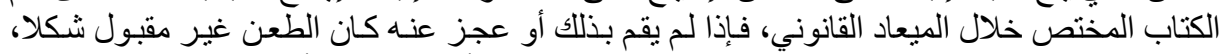
ويصلح الإيصال الصادر من قلم الكتاب كإثبات لإيداع مذكرة الأسباب وتقديم أوجه الطعن الطنا

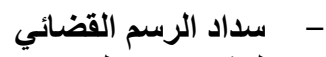

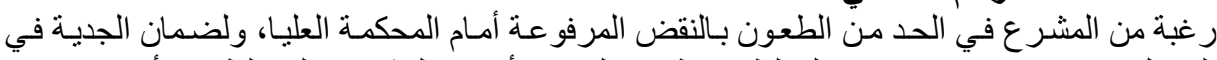

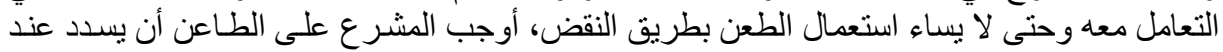

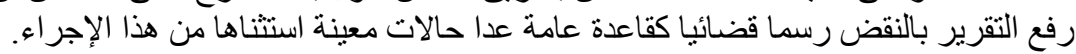


ثُالثا /ـ آثار مباشرة الطعن بالنقض على الحكم بالإدانة

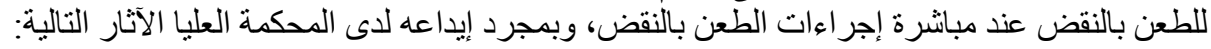
1 1- 1 الأثر الموقف:

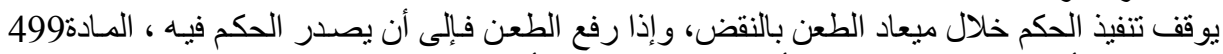

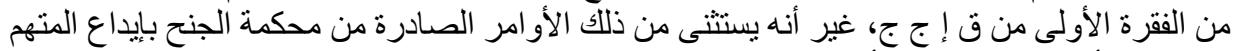

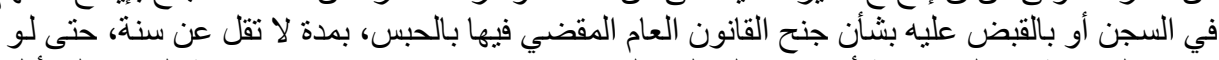

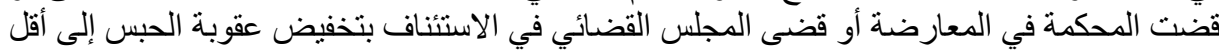

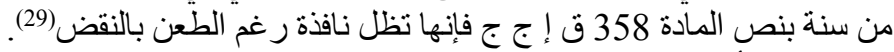

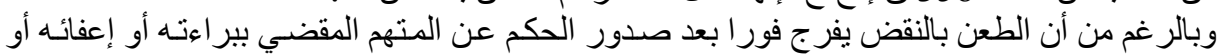

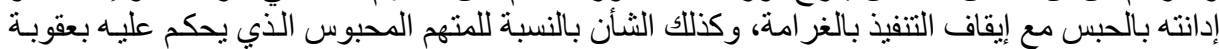

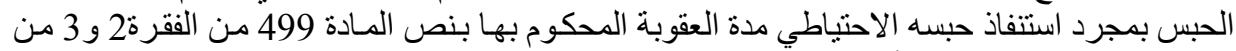

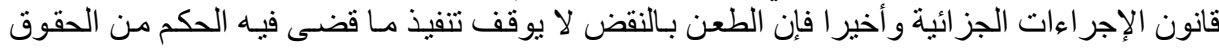

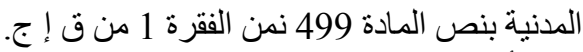

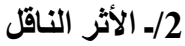

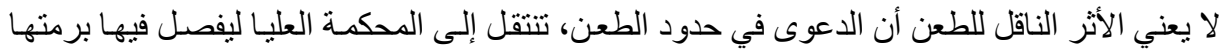

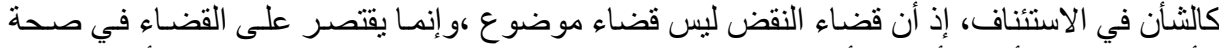

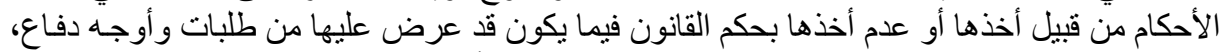

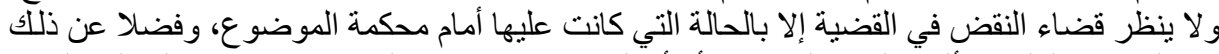

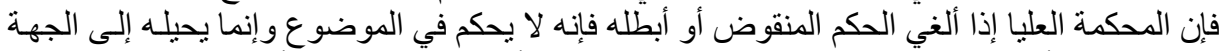

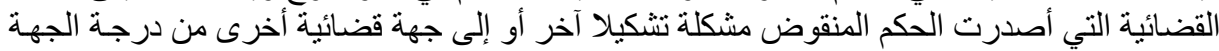

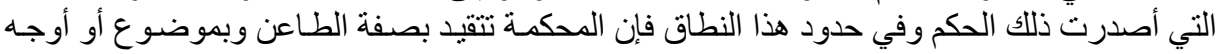
الطعن. 3/3- التقيد بصفة الطاعن: يتمثل تقبد المحكمة العليا بصفة الطاعن في أمرين:

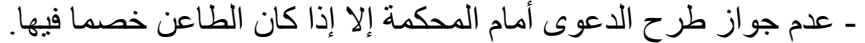

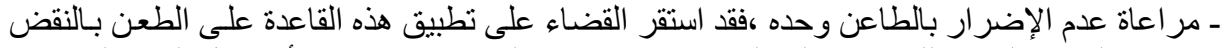

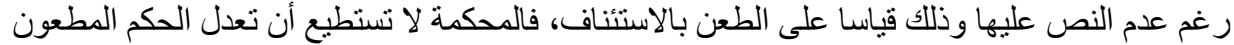

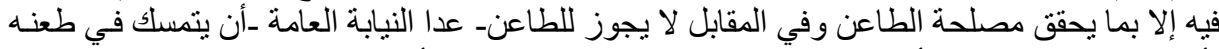

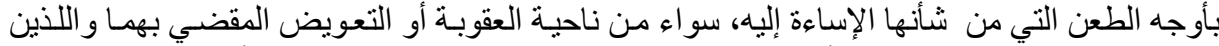

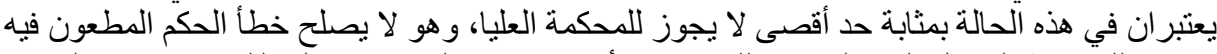

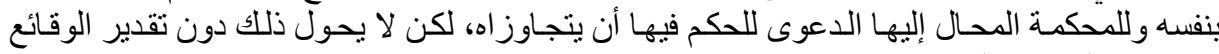

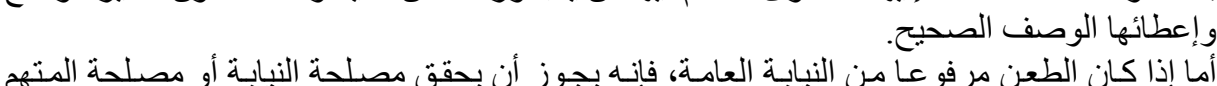

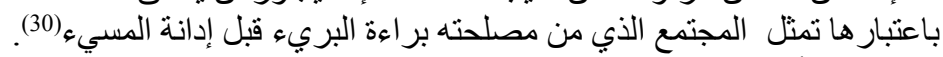

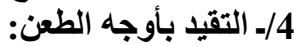

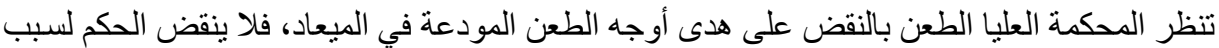

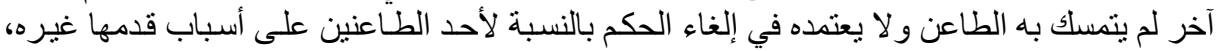

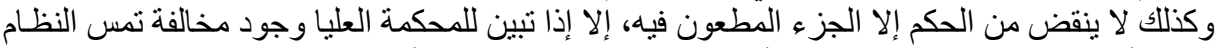
العام كأن تتعلق بتشكيل المحكمة التي أصدرت الحكم المطعون فيه، أو باختصاصها فإن المحكمة تثير ها لإنها من تلقاء نفسه. (31) 
خامسا/ـ التصدي لموضوع الطعن ومظاهر الرقابة عليه

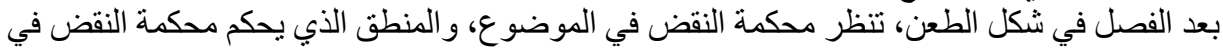

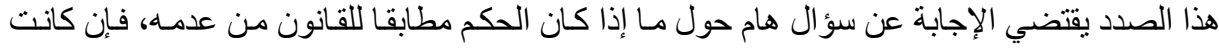

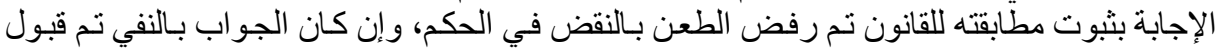

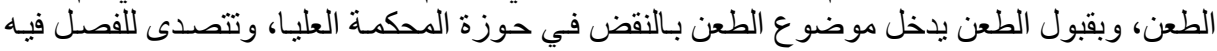

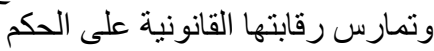
الجنائي المطعون فيه كما سنفصل فئن فيما سيأتي:

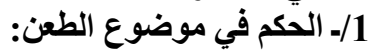
إن الحكم الصّادر في موضوع عالطوع الطعن قد يكون بالرفض أو بالقبول، وفيما يلي نتعرض لرفض الطعن ثم

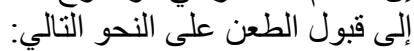

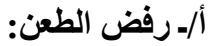

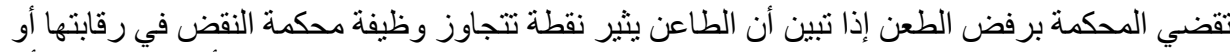

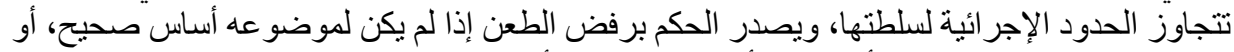

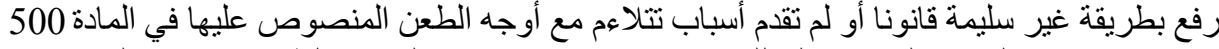

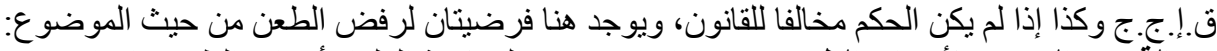

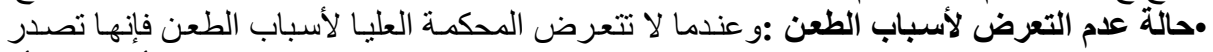

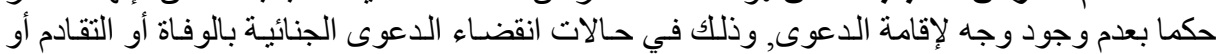

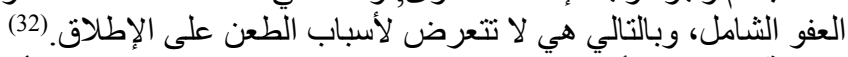

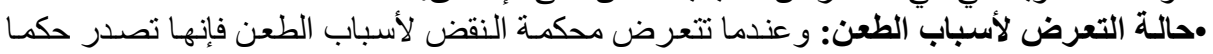

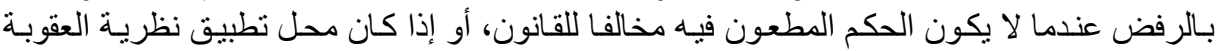

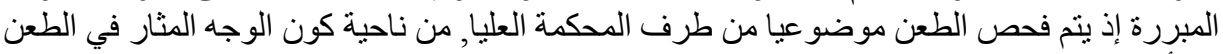

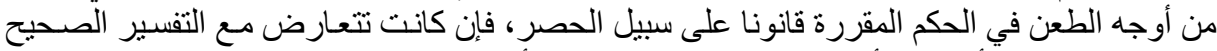

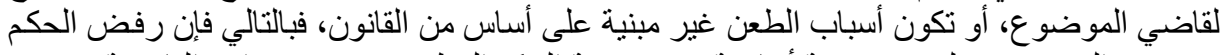

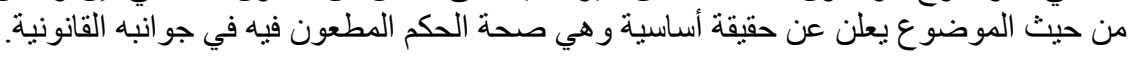

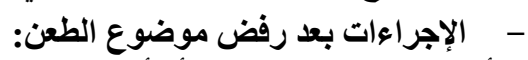

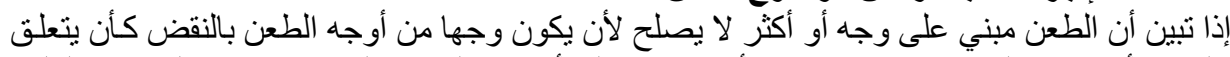

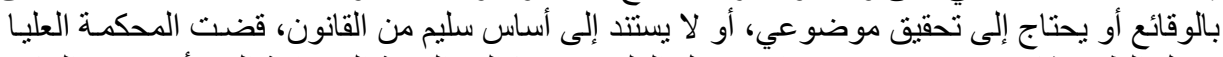

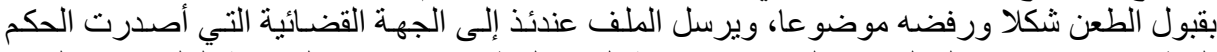

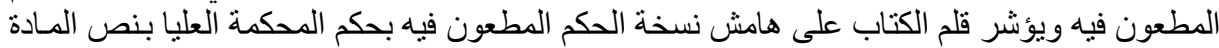

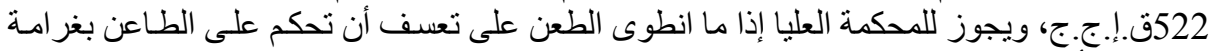

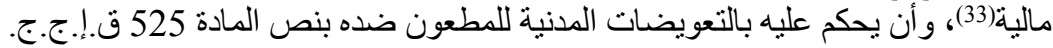

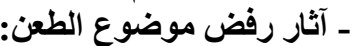

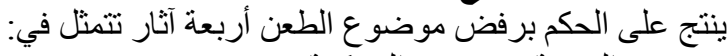
- مزروج القضية من حوزة المحكمة. ـاكتساب القرار أو الحكم محل الطعن لخاصية عدم القابلية للطعن.

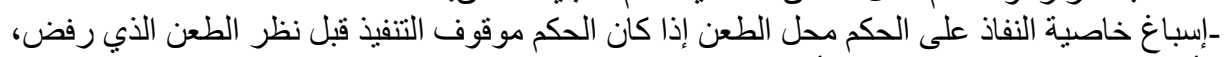

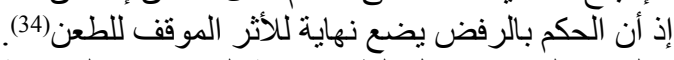

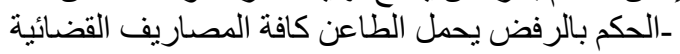

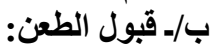
يشترط لقبول الطعن بالنقض أن يكون مبنيا على أحد الأوجه المنصوص علئها في المـادة 500 ق.إ.ج.ج

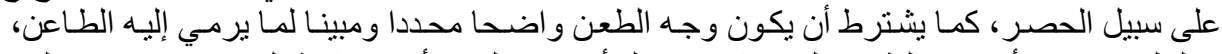

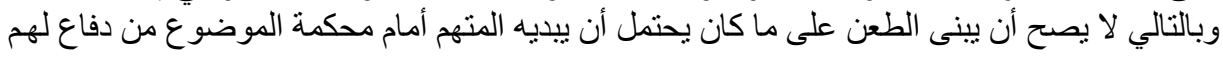




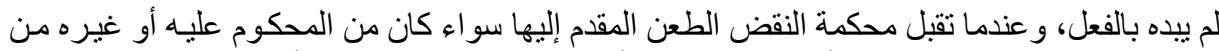

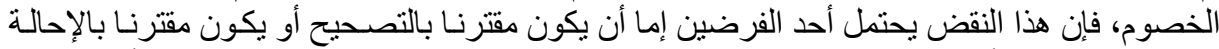

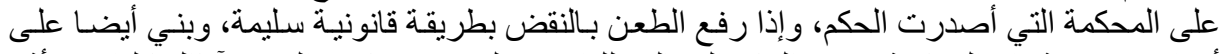

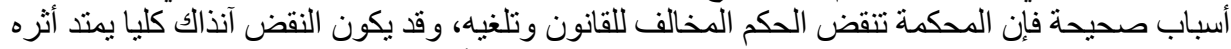

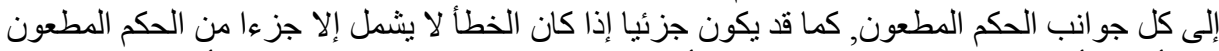

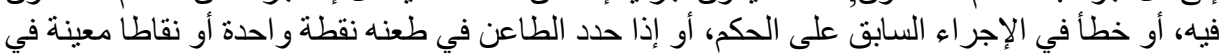

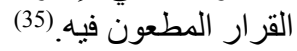

2/2 تصدي المحكمة العليا لأوجه الطعن من تلقاء نفسها

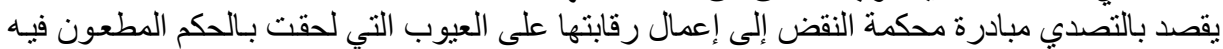

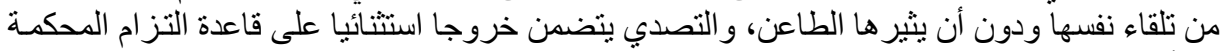

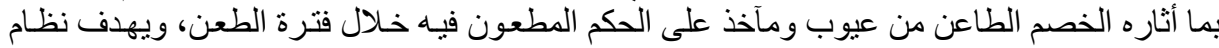

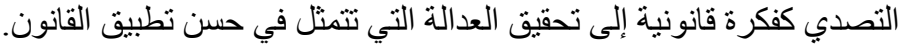

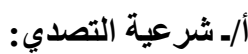
أجازت محكمة النفض الفرنسية التصدي لبعض العيوب التي تشوب الثشق القانوني للحكم على اعتبار

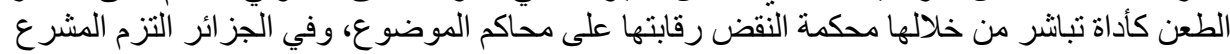

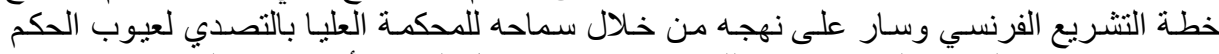

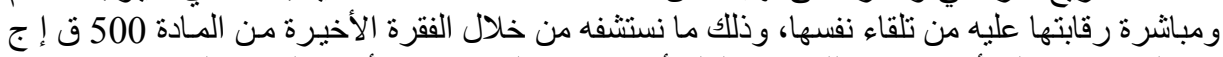

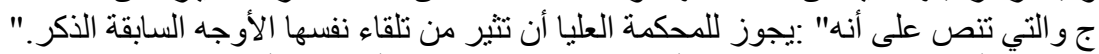
ب/ــ طبيعة التصدي المقرر للمحكمة العليا في المواد الجنائية والحكمة فيهاه:

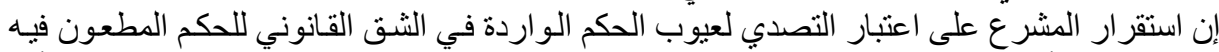

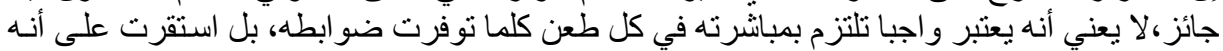

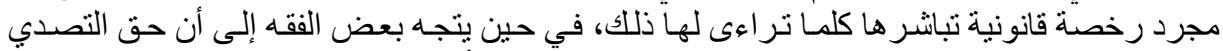

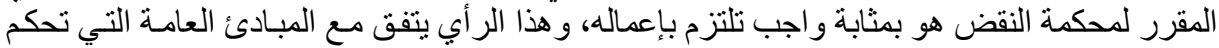

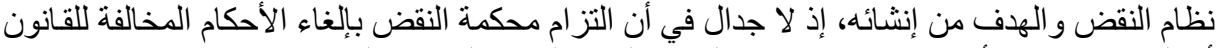

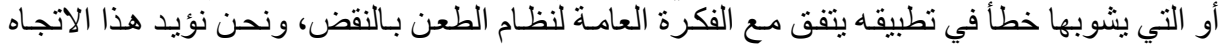

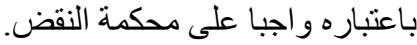

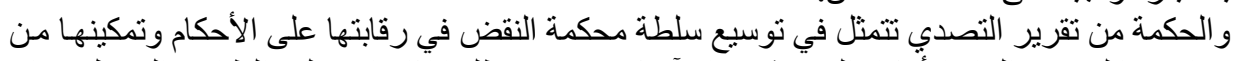

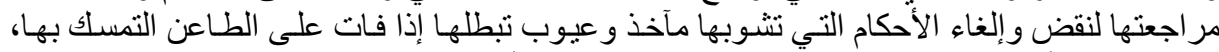

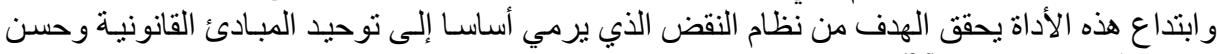

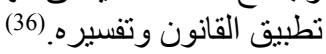

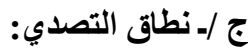

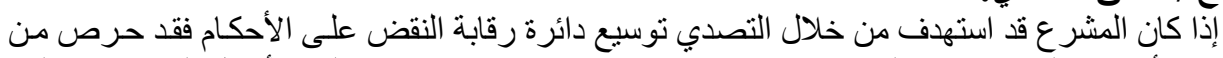

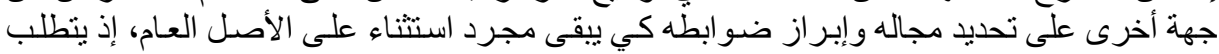

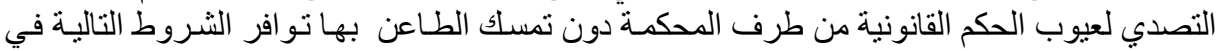

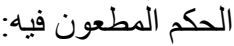

1-أن يكون هناك طعن بالنقض أثاره أحد الخصوم على الحكم الجنائي وأن يكون هذا الطعن مقبو لا من

طرف المحكمة العليا.

2-أن يكون التصدي لصالح المتهم في الثنق الجنائي إذ لا يجوز التصدي إذا انطوى على إسباءة لمركز

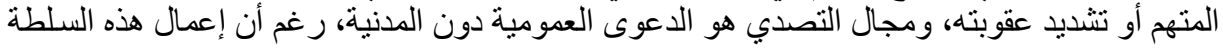


قد يؤدي إلى إلغاء الثق المدني بالتبعية، ذلك أن قيام علاقة الارنباط بين الثقين يقتضي ذلك لاعتبارات

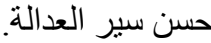

3-أن يكون التصدي لـجابهة عيوب معينة ويعني ذلك أن يكون هذا العيب وجها من أوجـه الطعن

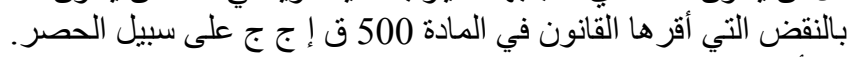

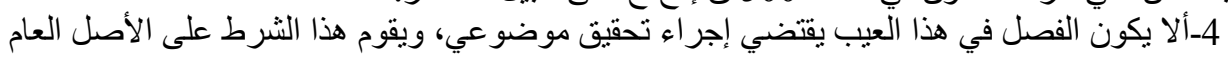

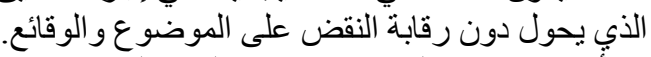

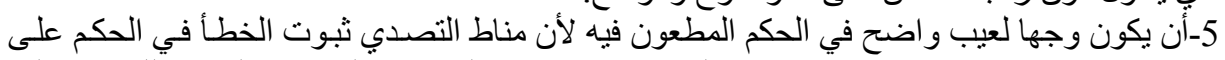

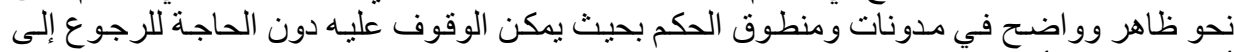

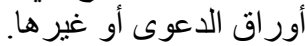

3/3- مظاهر رقابة النقض على الحكم الجنائي بالإدانة:

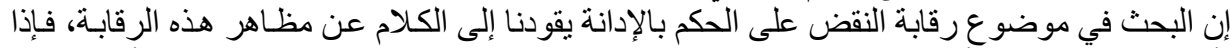

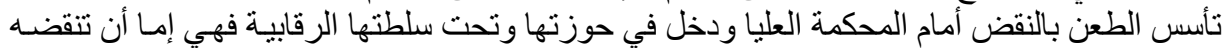

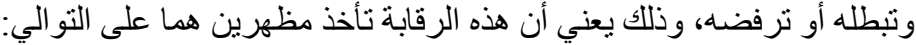

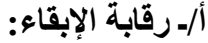

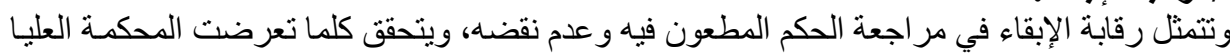

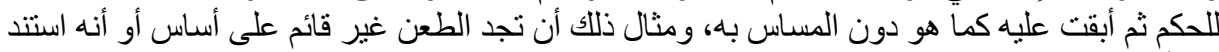

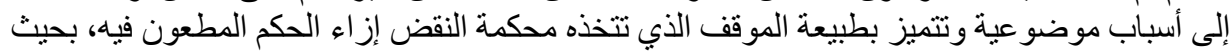

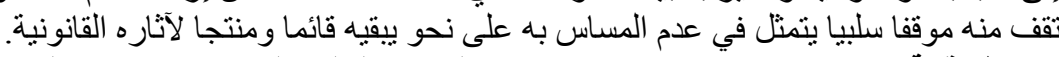

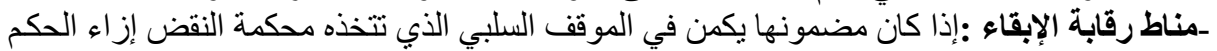

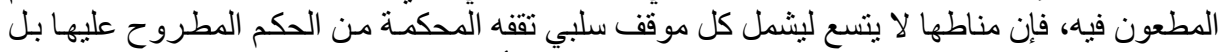

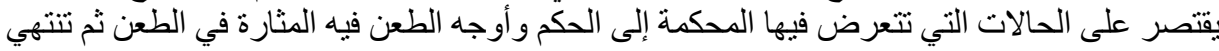

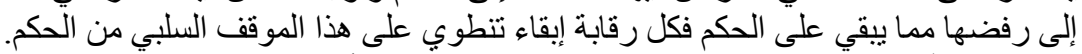

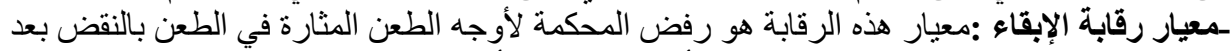

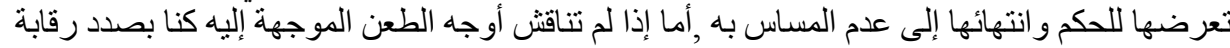

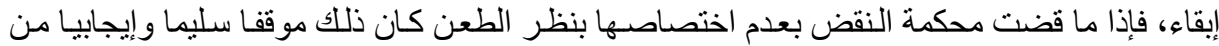

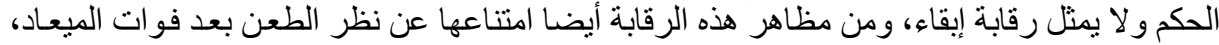

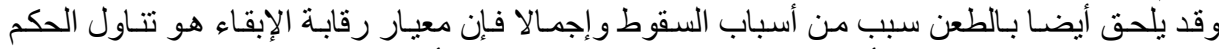

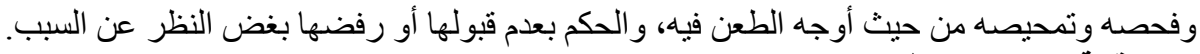

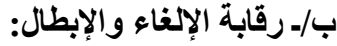

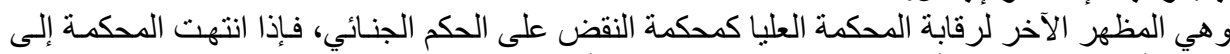

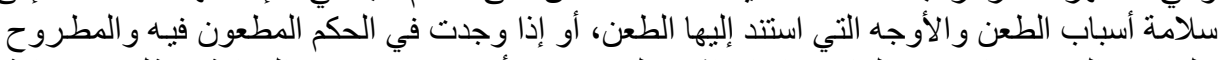

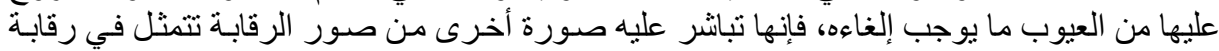

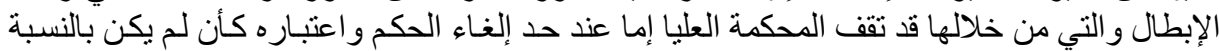

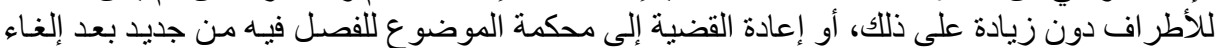
الحكم الأول، وتعرف الصورة الأولى برقابة الإلغاء و الثانية برقابة الإحالة بعد الإبطال. 


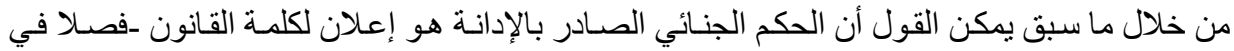

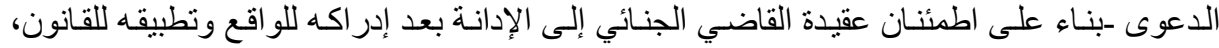

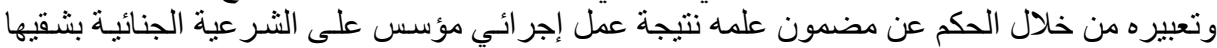

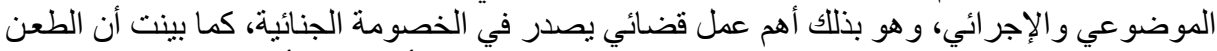

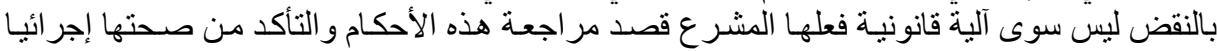
ومدى سلامة النتائج التي توصلت لئون إليها قانونيا.

و لا شك أن الخطأ في الحكم الصادر بالإدانة ليس حتميا، ولكنه لأسباب و عو امل متداخلة و اقع لم يجد

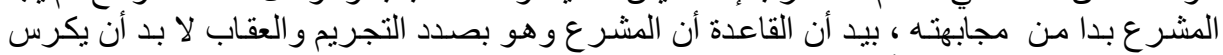

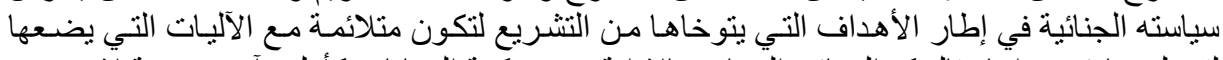

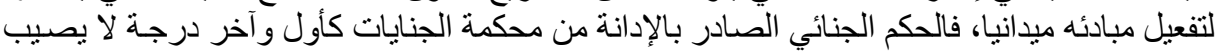

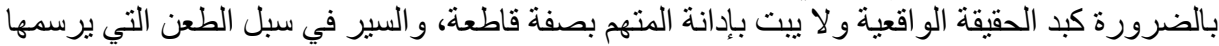

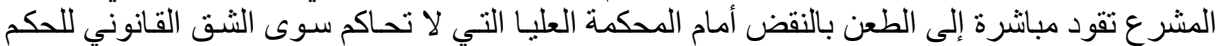

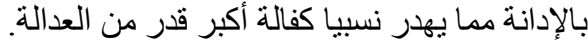

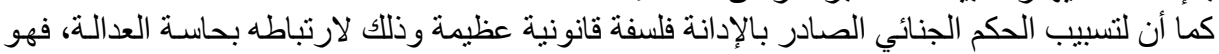

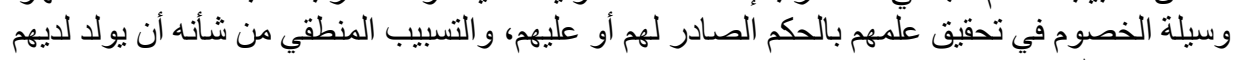

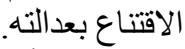

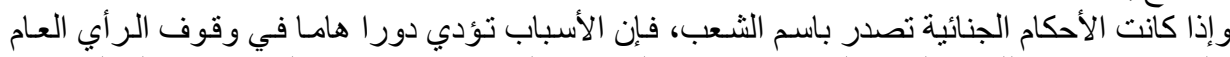

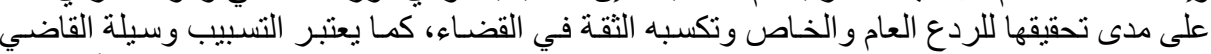

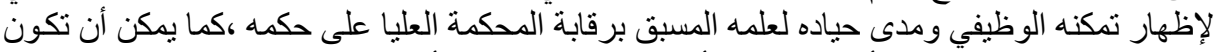

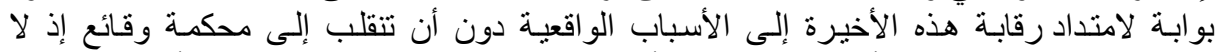

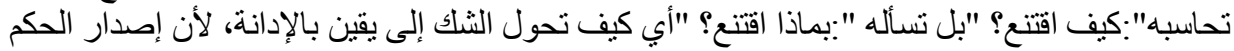

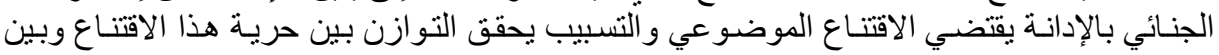
منهجا.

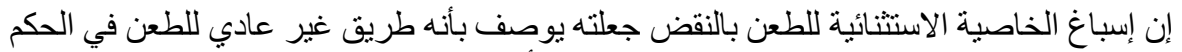

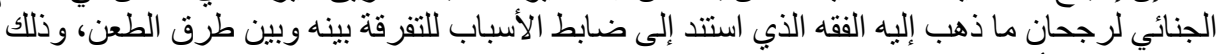

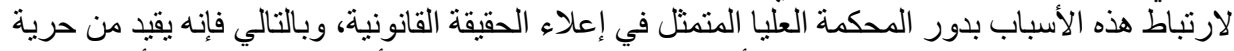

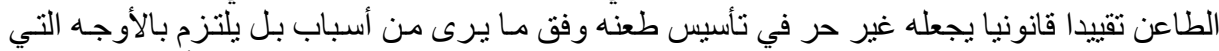

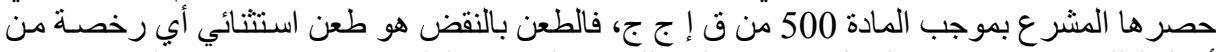

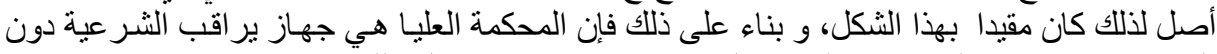

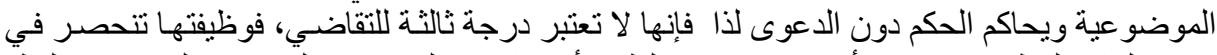

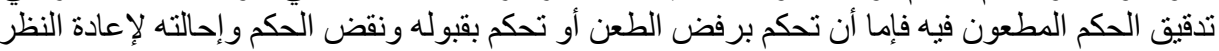

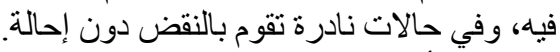

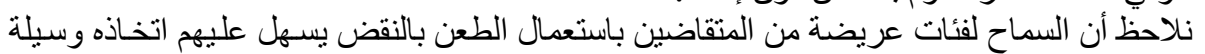

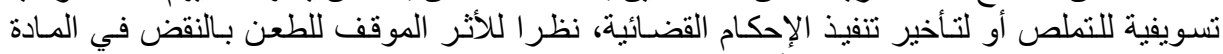

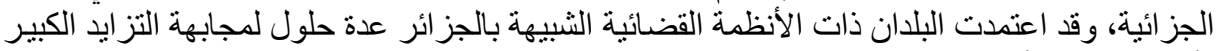

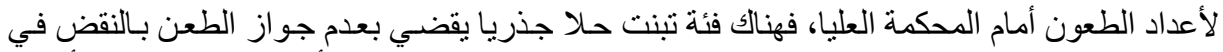

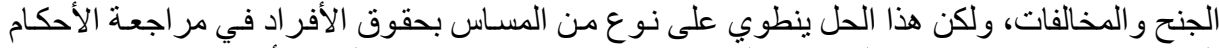

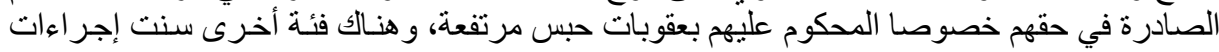

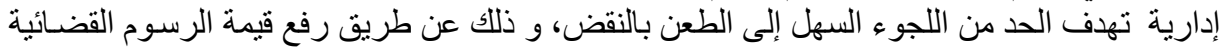
بشكل ملموس، إلى جانب مضاعفة حالات البطلان المؤدية إلى عدم قبول الطعن وكذا تدابير ظرفية ذلية ذات 


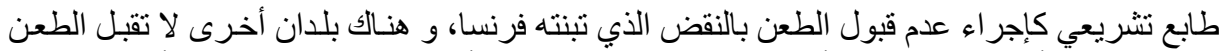

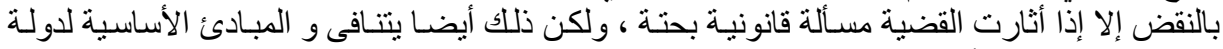

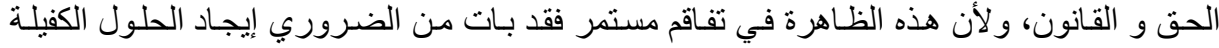

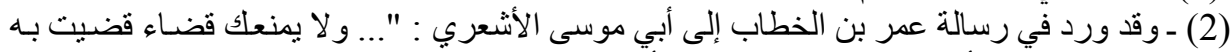

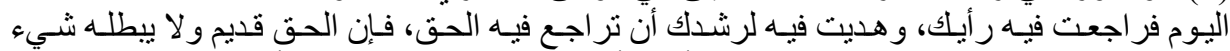

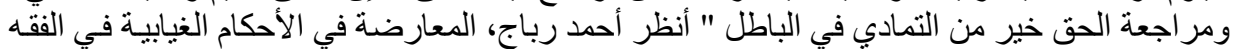

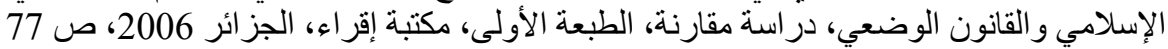

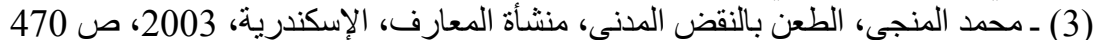

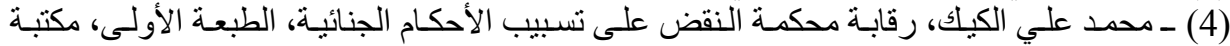

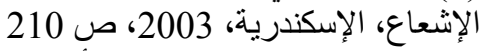

(5) ـ حسن صادق المرصفاوي، أصول الإجراءات الجز ائية، منشأة المعارف، الإسكندرية، 1996، ص

(6) ـ محمد صبحي نجم، شرح قانون الإجر اءات الجنائية الجزائري، ديوان المطبو عات الجامعية،

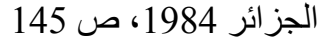

(7) ـ نظيـر فـرج مينـا، الموجز في الإجـر اءات الجزائيـة الجزائري، ديـوان المطبو عـات الجامعيـة،

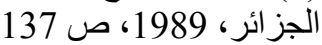

(8) ـ عدلي أمير خالد، أحكام قانون الإجر اءات الجزائية، دار الجامعة الجديدة، مصر، 2000، ص

(9) - جـلال ثروت و سليمان عبد المنعم، أصول الإجر اءات الجنائية، دار الجامعة الجديدة، مصر ،

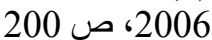

(10) - بحيث يختص بالتماس إعادة النظر بتصحيح مايشوب الحكم من أخطاء الو اقع النع

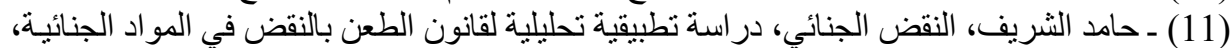

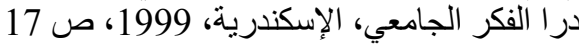

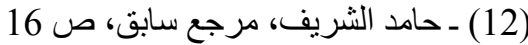

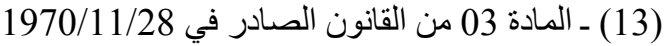

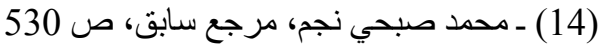

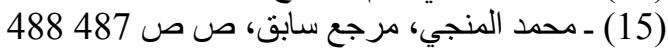

(16) -"la cour de cassation n'est pas un troisième degré de juridiction"Jaque Bore ,la cassation en matiere penal,librairie general de droit et jurisprudence, paris, 1985,p256

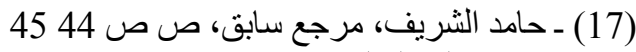

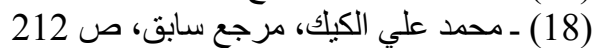

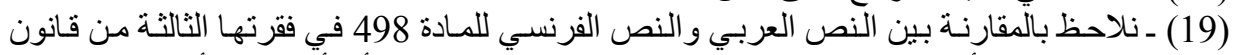

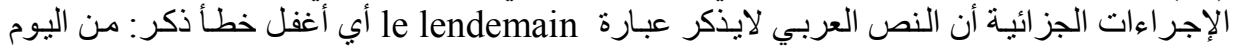

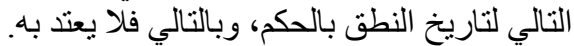

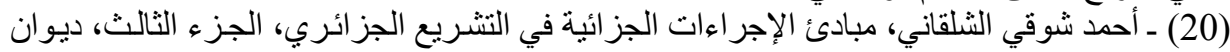

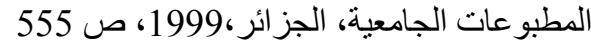

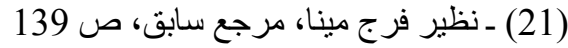




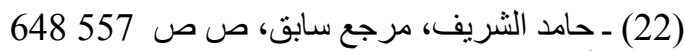

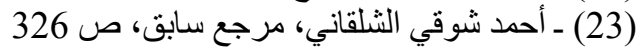

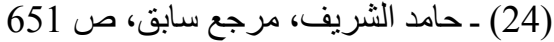

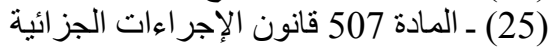

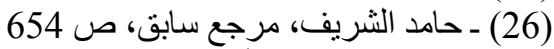

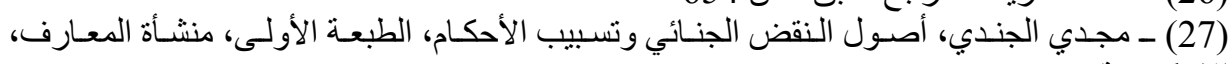

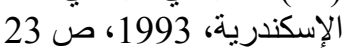

(28) ـ أحمد شوقي الثلقاني، مرجع سابق، ص صد 559

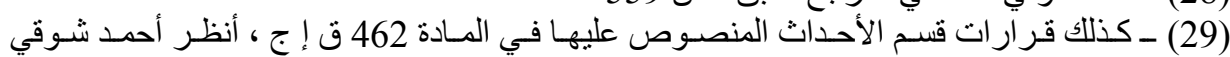

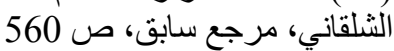

(30) - روابح إلهام شهرز اده، الطعن في الأحكام القضائية، دراسة تحليلية مقارنة، رسالة ماجستيير غير

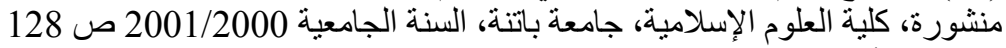

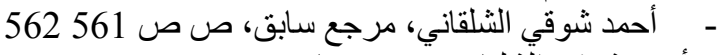

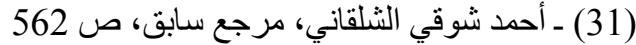

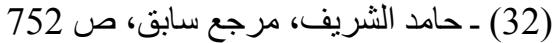

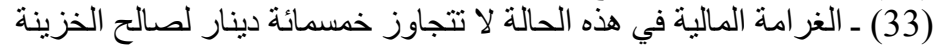

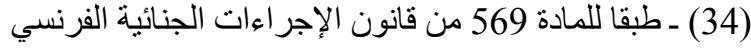

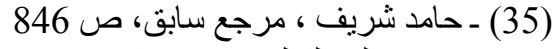

(36) ـ محمد علي الكيك، مرجع سابق، صن صن 227 